\title{
Formation and structures of cationic zirconium complexes in ternary systems rac- $(\mathrm{SBI}) \mathrm{ZrX}_{2} / \mathrm{AlBu}_{3}^{i} /\left[\mathrm{CPh}_{3}\right]\left[\mathrm{B}\left(\mathrm{C}_{6} \mathrm{~F}_{5}\right)_{4}\right](\mathrm{X}=\mathrm{Cl}, \mathrm{Me})$
}

\author{
Konstantin P. Bryliakov ${ }^{a, b, *}$, Evgenii P. Talsi ${ }^{a, b}$, Nina V. Semikolenova ${ }^{b}$, \\ Vladimir A. Zakharov ${ }^{b}$, Jörg Brand ${ }^{c}$, Carlos Alonso-Moreno ${ }^{\mathrm{d}}$, Manfred Bochmann ${ }^{\mathrm{d}, *, 1}$ \\ ${ }^{a}$ Boreskov Institute of Catalysis, Siberian Branch of the Russian Academy of Sciences, 630090 Novosibirsk, Russian Federation \\ ${ }^{\mathrm{b}}$ Department of Natural Sciences, Novosibirsk State University, 630090 Novosibirsk, Russian Federation \\ ${ }^{\mathrm{c}}$ Fachbereich Chemie, University of Konstanz, D-78457 Konstanz, Germany \\ ${ }^{\mathrm{d}}$ Wolfson Materials and Catalysis Centre, School of Chemical Sciences and Pharmacy, University of East Anglia, Norwich NR4 7TJ, United Kingdom
}

Received 12 September 2006; received in revised form 9 October 2006; accepted 16 October 2006

Available online 25 October 2006

\begin{abstract}
Using ${ }^{13} \mathrm{C},{ }^{1} \mathrm{H}$ and ${ }^{19} \mathrm{~F}$ NMR spectroscopy, formation of cationic species was studied in ternary systems $(\mathrm{SBI}) \mathrm{ZrX} \mathrm{X}_{2} / \mathrm{AlBu}{ }_{3}^{i} /$ $\left[\mathrm{CPh}_{3}\right]\left[\mathrm{B}\left(\mathrm{C}_{6} \mathrm{~F}_{5}\right)_{4}\right]$, where $\mathrm{X}=\mathrm{Cl}, \mathrm{Me}\left[(\mathrm{SBI})=\right.$ rac $\left.-\mathrm{Me}_{2} \mathrm{Si}(\mathrm{Ind})_{2}\right]$. In the first system $(\mathrm{X}=\mathrm{Cl})$, the ion pair $\left[(\mathrm{SBI}) \mathrm{Zr}(\mu-\mathrm{Cl})_{2} \mathrm{Zr}(\mathrm{SBI})\right]-$ $\left[\mathrm{B}\left(\mathrm{C}_{6} \mathrm{~F}_{5}\right)_{4}\right]_{2}(\mathbf{I V})$ predominates at low $\mathrm{Al} / \mathrm{Zr}$ ratios $(\mathrm{Al} / \mathrm{Zr}<10)$, whereas at higher $\mathrm{Al} / \mathrm{Zr}$ ratios $(\geqslant 20)$ in the absence of monomer mainly $\left[(\mathrm{SBI}) \mathrm{Zr}(\mu-\mathrm{H})\left(\mu-\mathrm{C}_{4} \mathrm{H}_{7}\right) \mathrm{AlBu}_{2}^{i}\right]\left[\mathrm{B}\left(\mathrm{C}_{6} \mathrm{~F}_{5}\right)_{4}\right](\mathbf{V})$ is formed. The binuclear complex $\left[(\mathrm{SBI}) \mathrm{Zr}(\mu-\mathrm{Cl})_{2} \mathrm{Zr}(\mathrm{SBI})\right]\left[\mathrm{B}\left(\mathrm{C}_{6} \mathrm{~F}_{5}\right)_{4}\right]_{2}$ has been characterized crystallographically. Species $\mathbf{V}$ is also formed in the system $\mathrm{X}=\mathrm{Me}$ at high $\mathrm{Al} / \mathrm{Zr}$ ratios. In the presence of $\mathrm{AlBu} \mathbf{u}_{3}^{i}$, IV displays activity in propylene polymerization and is the most likely precursor of the polymerizing species. Consistent mechanisms have been proposed for the reactions in these catalytic systems.
\end{abstract}

(C) 2006 Elsevier B.V. All rights reserved.

Keywords: Metallocenes; Catalysis; Activation; Intermediate; Triisobutyl aluminum; NMR

\section{Introduction}

Mixtures of triisobutyl aluminum (TIBA) and cation generating agents are widely used as co-catalysts in ternary systems for olefin polymerizations based on group IV metallocene complexes [1-9]. In some cases these TIBAbased activator systems are capable of increasing catalyst activities by $1-2$ orders of magnitude compared to methylalumoxane (MAO) activation [10-13]. It is now generally accepted that the active species in metallocene-based catalysts are electron-deficient alkyl complexes [LL'MR ${ }^{+}$] (where $\mathrm{R}=$ alkyl) paired with weakly coordinating count-

\footnotetext{
* Corresponding authors. Tel.: +7 383 3306877; fax: +7 3833308056.

E-mail addresses: bryliako@catalysis.ru (K.P. Bryliakov), m.bochmann@uea.ac.uk (M. Bochmann).

${ }^{1}$ Fax: +44 1603592044.
}

eranions, and it is thought that TIBA serves to generate a highly reactive metal alkyl species [14-18]. On the other hand, TIBA is known to be in equilibrium with $\mathrm{HAlBu}_{2}^{i}$ which could act as a hydride source [19], and the precise nature of the reaction products of TIBA with metallocenes under catalytic conditions is unknown.

Recently, Götz and co-workers have reported an NMR investigation of the products of successive reaction of $\mathrm{Cp}_{2} \mathrm{ZrCl}_{2}$ and $\mathrm{Ph}_{2} \mathrm{C}(\mathrm{Cp})(\mathrm{Flu}) \mathrm{ZrCl}_{2}$ with $\mathrm{Al}^{i} \mathrm{Bu}_{3}$ and $[\mathrm{PhN}-$ $\left.\mathrm{Me}_{2} \mathrm{H}\right]\left[\mathrm{B}\left(\mathrm{C}_{6} \mathrm{~F}_{5}\right)_{4}\right]$ at elevated temperature $\left(60^{\circ} \mathrm{C}\right)[20]$. They found the surprising formation of hydrido-bridged $\mathrm{Zr}-\mathrm{Al}$ binuclear species, although some intermediates could only be tentatively identified. In view of our earlier studies of the kinetics of the high-activity catalysts (SBI) $\mathrm{ZrX}_{2} / \mathrm{TIBA} /$ $\left[\mathrm{CPh}_{3}\right]\left[\mathrm{B}\left(\mathrm{C}_{6} \mathrm{~F}_{5}\right)_{4}\right]\left(\mathrm{SBI}=r a c-\mathrm{Me}_{2} \mathrm{Si}(\mathrm{Ind})_{2}, \mathrm{X}=\mathrm{Cl}\right.$ or $\left.\mathrm{Me}\right)$ $[18,21]$ we were therefore interested in elucidating the role of TIBA under these conditions. In this paper, ${ }^{1} \mathrm{H},{ }^{13} \mathrm{C}$ and ${ }^{19} \mathrm{~F}$ NMR spectroscopic study of this system is 
presented, and several types of cationic zirconium species have been detected and characterized.

\section{Results and discussion}

\subsection{The system (SBI) $Z r C l_{2} / \mathrm{AlBu}_{3}^{i} /\left[C P h_{3}\right]\left[B\left(C_{6} F_{5}\right)_{4}\right]$}

Reaction of $(\mathrm{SBI}) \mathrm{ZrCl}_{2}$ (I) with $\mathrm{AlBu}_{3}^{i}$ at room temperature in an $\mathrm{Al} / \mathrm{Zr}$ ratio of $2: 1$ in toluene lead to a mixture of I and (SBI) ZrClBu${ }^{i}$ (II) (I/II ratio 2.3:1). At $\mathrm{Al} / \mathrm{Zr}=5: 1$, $90 \%$ conversion to II was the case (see Section 4 ). No other species (i.e. $\mathrm{Zr}$ hydrides, etc.) rather than I and II were observed in the mixture. The identity of II was confirmed by independent synthesis via reaction of $\mathbf{I}$ with ${ }^{i} \mathrm{BuMgCl}$ in toluene at $0-10{ }^{\circ} \mathrm{C}$ (see Section 4). An orange solid was formed almost quantitatively (Scheme 1). The complex is unstable in toluene and decays within hours at room temperature at $\mathrm{Al} / \mathrm{Zr}=5: 1$.

Addition of $\left[\mathrm{CPh}_{3}\right]\left[\mathrm{B}\left(\mathrm{C}_{6} \mathrm{~F}_{5}\right)_{4}\right]$ to $(\mathrm{SBI}) \mathrm{ZrClBu}^{i}$ formed in situ at room temperature rapidly produces a blue or green-blue oily residue as the lower phase, which contains the target ionic compounds, and a clear supernatant which contains TIBA, $\mathrm{HCPh}_{3}$ and isobutene. NMR spectra were run either directly on the oily liquid, or $20 \mathrm{vol} \%$ of a polar solvent (i.e. 1,2-difluorobenzene or 1,2-dichlorobenzene) was added to the samples to obtain a homogeneous solution. Two zirconium species were detected in the NMR spectra of the oily phase, their ratio depending on the $\mathrm{Al} /$ $\mathrm{Zr}$ ratio used.

At low $\mathrm{Al} / \mathrm{Zr}$ ratios (5-10) a new zirconium species IV was detected as a major product. In principle, under these conditions one might expect the formation of a cationic methallyl complex $\left[(\mathrm{SBI}) \mathrm{Zr}\left(\eta_{3}-\mathrm{CH}_{2} \mathrm{CMeCH}_{2}\right)\right]\left[\mathrm{B}\left(\mathrm{C}_{6} \mathrm{~F}_{5}\right)_{4}\right]$ similar to those described previously $[22,23]$. However, no spectroscopic evidence for the formation of such species was obtained. Compound IV displays two characteristic doublets for the cyclopentadienyl protons of the SBI ligand in the ${ }^{1} \mathrm{H}$ spectra, at $\delta 5.39$ and 6.42 (with the corresponding ${ }^{13} \mathrm{C}$ peaks at $\delta 121.6$ and 122.6 , Fig. 1), and a single resonance for $\mathrm{Si}-\mathrm{Me}$ groups at $\delta 0.84$. Apparently, $\mathbf{I V}$ is an ionic product with $\left[\mathrm{B}\left(\mathrm{C}_{6} \mathrm{~F}_{5}\right)_{4}\right]^{-}$as counter-anion $\left({ }^{19} \mathrm{~F}\right.$ NMR: $\delta$ $-133.3,-163.9,-167.7$ ) (cf. [22,23]), its cationic part displaying $C_{2}$-symmetry. No coordination of the anion to $\mathrm{Zr}$ was observed in the ${ }^{19} \mathrm{~F}$ NMR spectra. The $\mathrm{C}_{5}$ part of IV is also characterized by a single ${ }^{13} \mathrm{C}$ peak at $\delta 88.2(2 \mathrm{C}$, assigned to $\mathrm{Si}-C(\mathrm{Cp})$ carbons on the basis of long range $\mathrm{C}, \mathrm{H}$-correlated spectra). Based on these spectral data, and taking into account the documented capability of cyclopen-

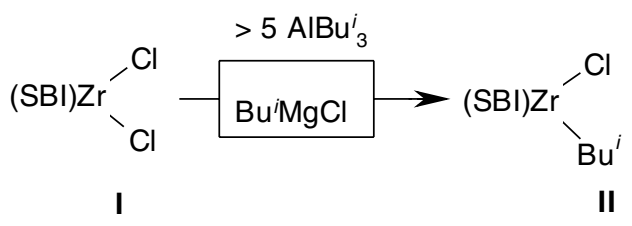

Scheme 1. Preparation of complex II.

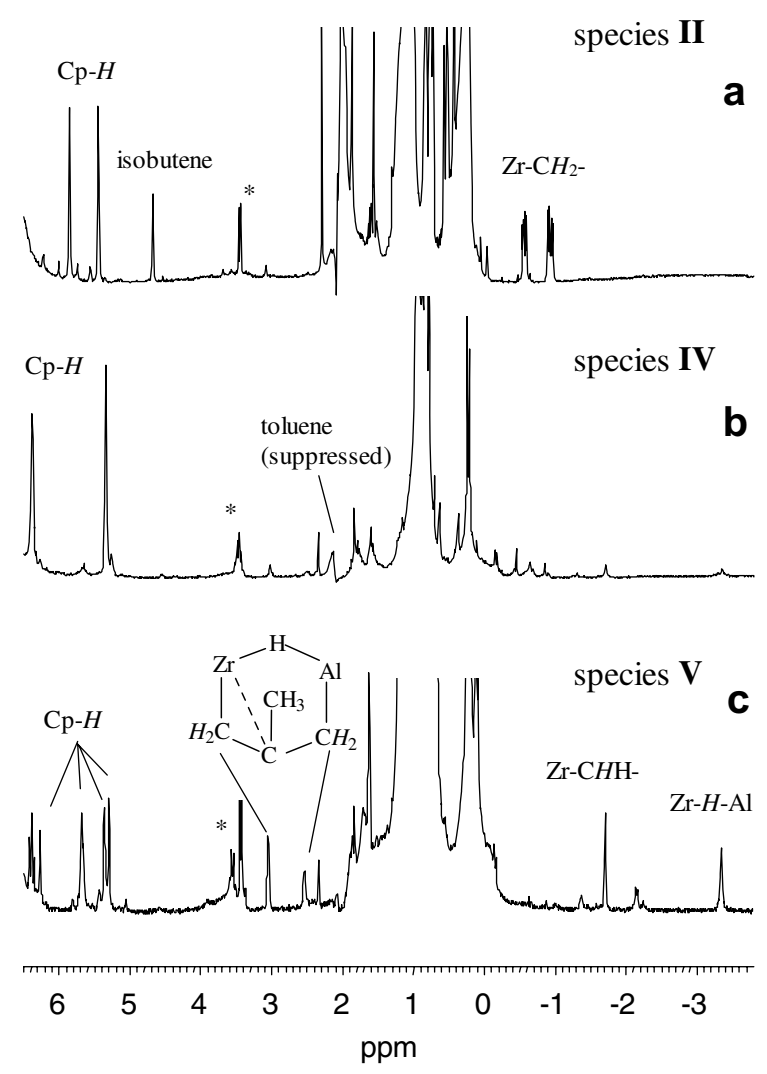

Fig. 1. ${ }^{1} \mathrm{H}$ NMR spectra $\left(20^{\circ} \mathrm{C}\right)$ of the systems $(\mathrm{SBI}) \mathrm{ZrCl}_{2} / \mathrm{TIBA}=1: 5$, toluene (a), ( $\mathrm{SBI}) \mathrm{ZrCl}_{2} / \mathrm{TIBA} /\left[\mathrm{CPh}_{3}\right]\left[\left(\mathrm{C}_{6} \mathrm{~F}_{5}\right)_{4}\right]=1: 5: 1$, toluene/1,2-dichlorobenzene (b), sample (b) after 30 min stirring with extra 25 -fold excess of TIBA (c). Asterisks mark impurities in TIBA

tadienyl zirconium derivatives to form bis( $\mu$-chloro) bridged dications $[24,25]$, IV could be identified as [(SBI)Zr$\left.(\mu-\mathrm{Cl})_{2} \mathrm{Zr}(\mathrm{SBI})\right]\left[\mathrm{B}\left(\mathrm{C}_{6} \mathrm{~F}_{5}\right)_{4}\right]_{2}$ ion pair. No spectroscopic evidence for the formation of meso- and rac-like diastereomers (as in the case of $\left[\{(\mathrm{SBI}) \mathrm{ZrMe}\}_{2}(\mu-\mathrm{Me})\right]\left[\mathrm{B}\left(\mathrm{C}_{6} \mathrm{~F}_{5}\right)_{4}\right]$ for example [26]) was obtained. Apparently, one of the diastereomers strictly prevails in our case. On the basis of the spectroscopic and literature data [20], a possible route for the formation of IV was derived (Scheme 2).

The formation of IV can be explained by $\beta$-hydride abstraction by $\mathrm{CPh}_{3}^{+}$from II, presumably to give the labile cation $\left[(\mathrm{SBI}) \mathrm{Zr}(\mathrm{Cl})-\mathrm{CH}_{2} \mathrm{C}^{(+)}\left(\mathrm{CH}_{3}\right)_{2}\right]$, followed by loss of isobutene and generation of IV. The NMR spectra showed that IV does not react with isobutene when the latter is present in the sample. By contrast, injection of $10 \mathrm{~mL}$ of propylene gas into the NMR sample containing a slightly pre-cooled solution of complex IV with residual TIBA (see Section 4) showed fast (within seconds) gas consumption, followed by the formation of solid polymer in the upper part of the sample $\left({ }^{13} \mathrm{C}: \delta 46.4\left(\mathrm{CH}_{2}\right), 27.8(\mathrm{CH})\right.$, $\left.22.0\left(\mathrm{CH}_{3}\right)\right)$.

To corroborate our assignment of the species IV, we prepared it independently. Taking into account the well documented tendency of $\left[\mathrm{CPh}_{3}\right]\left[\mathrm{B}\left(\mathrm{C}_{6} \mathrm{~F}_{5}\right)_{4}\right]$ to abstract a methyl-anion from methylated metal complexes, one could expect the reaction of $(\mathrm{SBI}) \mathrm{ZrClMe}$ with $\left[\mathrm{CPh}_{3}\right]\left[\mathrm{B}\left(\mathrm{C}_{6} \mathrm{~F}_{5}\right)_{4}\right]$ 


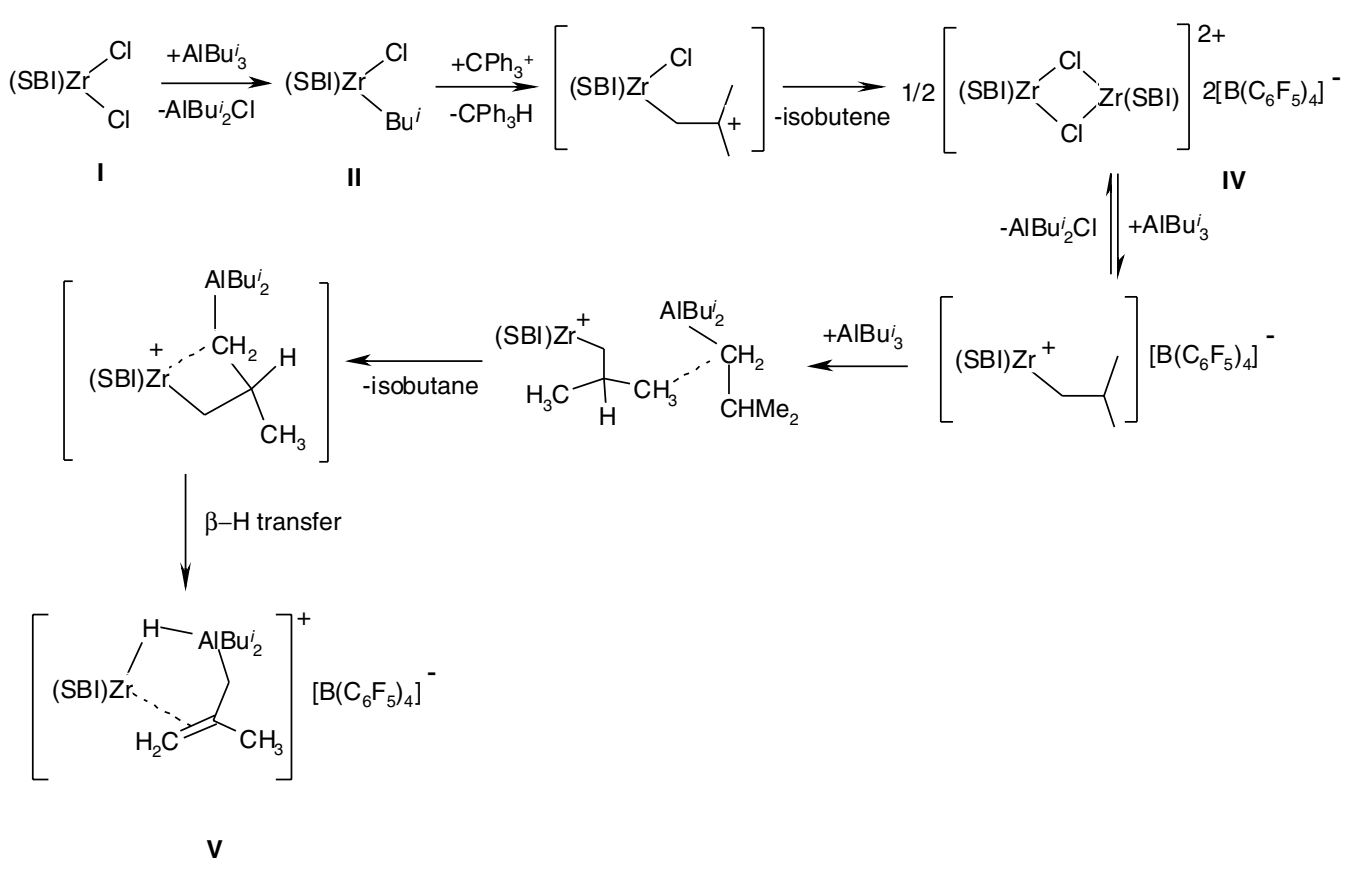

Scheme 2. Suggested routes for the formation of intermediates IV and $\mathbf{V}$.

to lead to species IV. The monomethylated zirconocene complex was prepared in situ by dissolution of $(\mathrm{SBI}) \mathrm{ZrCl}_{2}$ in toluene solution of $\mathrm{AlMe}_{3}$ at an $\mathrm{Al} / \mathrm{Zr}$ ratio of 7.5 (at this particular ratio, in agreement with the work of Brintzinger and Beck [27], we obtained $90 \%$ conversion of the starting $\mathrm{Zr}$ complex to the monomethyl product). Then, $\left[\mathrm{CPh}_{3}\right]\left[\mathrm{B}\left(\mathrm{C}_{6} \mathrm{~F}_{5}\right)_{4}\right]$ was added $(\mathrm{Zr} / \mathrm{B}=1: 1)$. As expected, the situation was somewhat complicated by the excess of $\mathrm{AlMe}_{3}$ due to its ability to form heterobinuclear complexes with $\mathrm{Zr}$ [26]. Indeed, a mixture of two cationic $\mathrm{Zr}$ complexes was obtained. The major one (ca. $60 \%$ ) was the heterobinuclear $\mathrm{Zr}$ complex $\left[(\mathrm{SBI}) \mathrm{Zr}(\mu-\mathrm{Me})_{2} \mathrm{AlMe}_{2}\right]\left[\mathrm{B}\left(\mathrm{C}_{6} \mathrm{~F}_{5}\right)_{4}\right]$ (for NMR characterization of heterobinuclear zirconocene complexes see $[26,28,29])$, while the minor one (ca. $40 \%$ ) was the target species IV. This experiment confirms clearly that IV does not contain any alkyl ligands at the $\mathrm{Zr}$ atom. Species IV is not unusual and can be obtained with aluminum alkyls other than TIBA [24,25] (see Fig. 2).

Alternatively, IV was successfully generated by the synthetic procedure described by Jordan et al. for similar zirconocene complexes [25]. At the first stage, $(\mathrm{SBI}) \mathrm{ZrMe}_{2}$ was reacted with. 1.0 equiv. of $\left[\mathrm{CPh}_{3}\right]\left[\mathrm{B}\left(\mathrm{C}_{6} \mathrm{~F}_{5}\right)_{4}\right]$ to obtain $[(\mathrm{SBI}) \mathrm{ZrMe}(\mathrm{S})]\left[\mathrm{B}\left(\mathrm{C}_{6} \mathrm{~F}_{5}\right)_{4}\right]$ III (cf. [11]), (where $\mathrm{S}$ stands for solvent molecule), followed by the addition of $\mathrm{Me}_{3} \mathrm{SiCl}$ to produce the expected species IV (Scheme 3).

Complex IV can be stored in a refrigerator for several days both in the oily phase and in toluene/1,2-dichlorobenzene or toluene/1,2-difluorobenzene solution. However, when species IV formed in the system (SBI) $\mathrm{ZrCl}_{2} \mathrm{AlBu}_{3}^{i}$ $\left[\mathrm{CPh}_{3}\right]\left[\mathrm{B}\left(\mathrm{C}_{6} \mathrm{~F}_{5}\right)_{4}\right]=1: 5: 1$ (see Section 4) was exposed to ambient temperature for ca. 1 week, single crystals formed. $X$-ray diffraction revealed the $[(\mathrm{SBI}) \mathrm{Zr}(\mu-$ $\left.\mathrm{Cl})_{2} \mathrm{Zr}(\mathrm{SBI})\right]\left[\mathrm{B}\left(\mathrm{C}_{6} \mathrm{~F}_{5}\right)_{4}\right]_{2}$ structure for IV (Fig. 3), similar
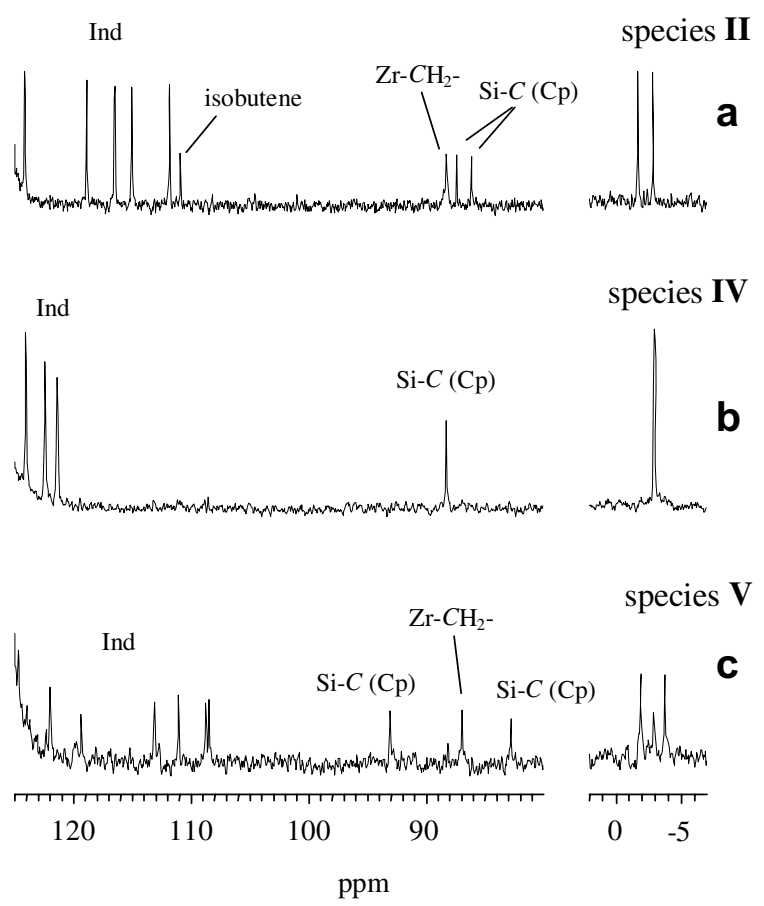

Fig. 2. ${ }^{13} \mathrm{C}$ NMR spectra $\left(20^{\circ} \mathrm{C}\right)$ of the systems $(\mathrm{SBI}) \mathrm{ZrCl}_{2} / \mathrm{TIBA}=1: 10$, toluene (a), $(\mathrm{SBI}) \mathrm{ZrCl}_{2} / \mathrm{TIBA} /\left[\mathrm{CPh}_{3}\right]\left[\left(\mathrm{C}_{6} \mathrm{~F}_{5}\right)_{4}\right]=1: 5: 1$ toluene/1,2-dichlorobenzene (b), sample (b) after 30 min stirring with extra 25 -fold excess of TIBA (c). In the higher-field part, signals of $\mathrm{Si}-\mathrm{CH}_{3}$ carbons are presented.

to the previously reported $\left[\left\{\mathrm{Cp}_{2}^{R} \mathrm{Zr}(\mu-\mathrm{Cl})\right\}_{2}\right]\left[\mathrm{B}\left(\mathrm{C}_{6} \mathrm{~F}_{5}\right)_{4}\right]_{2}$ $\left(\mathrm{Cp}^{\mathrm{R}}=\mathrm{Cp}, \mathrm{C}_{5} \mathrm{H}_{4} \mathrm{Me}\right)[25]$.

At higher $\mathrm{Al} / \mathrm{Zr}$ ratios, magnetic stirring at room temperature for $10-30 \mathrm{~min}$ afforded a brown oily phase containing a new cationic species $\mathbf{V}$, along with toluene, 


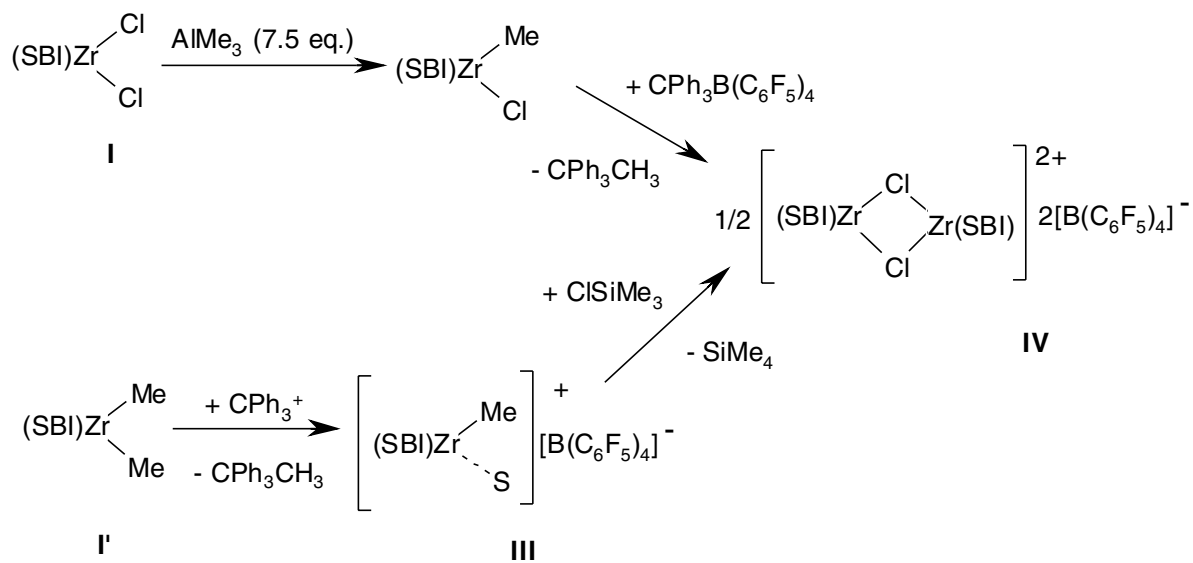

Scheme 3. Independent syntheses of complex IV. For details see Section 4.

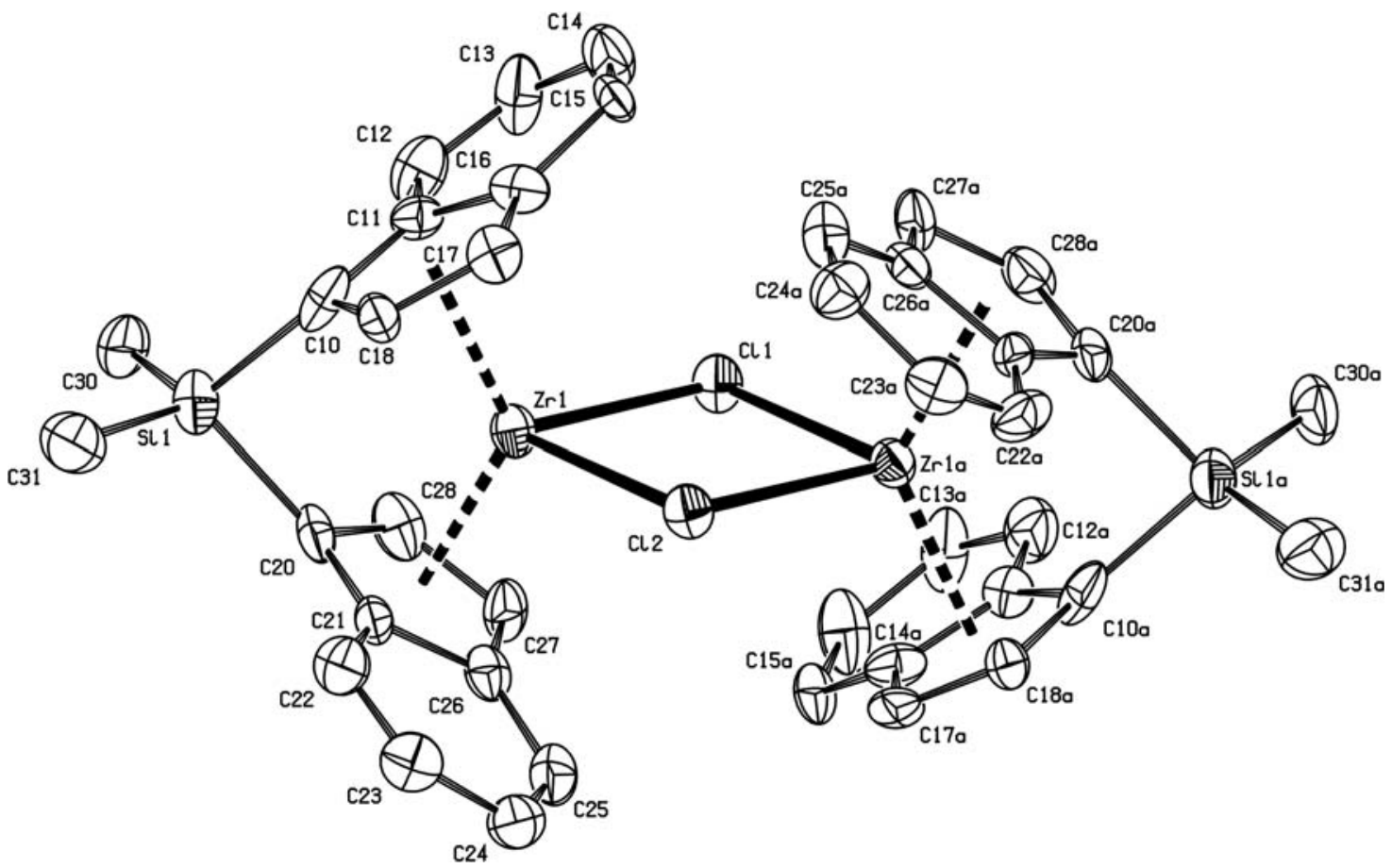

Fig. 3. ORTEP [30] plot of the $\mu_{2}-\mathrm{Cl}$ bridged dication $\left[(\mathrm{SBI}) \mathrm{Zr}(\mu-\mathrm{Cl})_{2} \mathrm{Zr}(\mathrm{SBI})\right]\left[\mathrm{B}\left(\mathrm{C}_{6} \mathrm{~F}_{5}\right)_{4}\right]_{2}(\mathrm{IV})$. $\mathrm{H}$ atoms omitted for clarity (displacement ellipsoids $50 \%$ ). Symmetry operation for atoms whose labels are marked with an a: $(-x, y, 0.5-z)$.

residual IV and aluminum alkyls. For example, at an $\mathrm{Al} / \mathrm{Zr}$ ratio of 30 , the $[\mathbf{I V}] /[\mathbf{V}]$ ratio amounted to $1: 4$ after $30 \mathrm{~min}$ stirring. The NMR spectra of $\mathbf{V}$ provide evidence for an allyl-bridged heterobinuclear complex, similar to the structure proposed by Götz for a $\mathrm{Me}_{2} \mathrm{C}(\mathrm{Cp})(\mathrm{Flu})$ complex [20]. Species $\mathbf{V}$ displays $C_{1}$ symmetry, according to two ${ }^{13} \mathrm{C}$ resonances for two non-equivalent $\mathrm{Si}-\mathrm{CH}_{3}$ groups at $\delta-1.99$ and -3.82 . The $\mathrm{Zr}-\mathrm{CH}_{2}$ and $\mathrm{Al}-\mathrm{CH}_{2}$ peaks were found at $\delta$ 86.9 and 53.8, respectively, and the $\mathrm{CH}_{2}=C \mathrm{Me}$-signal was observed at $\delta 166.6$, i.e. at a chemical shift characteristic of a methallylic structure. The NMR data for the $\left[\mathrm{B}\left(\mathrm{C}_{6} \mathrm{~F}_{5}\right)_{4}\right]^{-}$ anion in $\mathbf{V}$ are as expected $\left({ }^{19} \mathrm{~F}: \delta-133.0,-163.7,-167.5\right)$ $[22,23]$. This methallylic complex is stable for at least 1 day at room temperature. The route proposed for the conver- sion of $\mathbf{I V}-\mathbf{V}$ remains hypothetical, since no direct spectroscopic evidence for the elusive intermediates (placed in square brackets in Scheme 2) was obtained. The evolution of isobutane could not be confirmed unequivocally, since $\mathbf{V}$ is obtained at a high excess of TIBA which always contains isobutane and isobutene as impurities.

It is known that some $\mathrm{HAlBu}_{2}^{i}$ (DIBAH) is always present in commercial TIBA samples, thus at high $\mathrm{Al} / \mathrm{Zr}$ ratios DIBAH might be expected to affect the chemical reactions in the above system. The possible role of $\mathrm{HAlBu}_{2}^{i}$ was tested in two experiments. In the first one, addition of $\left[\mathrm{CPh}_{3}\right]$ $\left[\mathrm{B}\left(\mathrm{C}_{6} \mathrm{~F}_{5}\right)_{4}\right](\mathrm{Zr} / \mathrm{B}=1: 1)$ to a mixture of $(\mathrm{SBI}) \mathrm{ZrCl}_{2} / \mathrm{TIBA}$ / DIBAH ( $\mathrm{Zr}: \mathrm{Al}: \mathrm{Al}=1: 3.5: 1.5)$ resulted in the generation of IV along with unidentified minor species having broad 
${ }^{1} \mathrm{H}$ NMR peaks. Further addition of TIBA $(\mathrm{Al} / \mathrm{Zr}=20)$ led to conversion to $\mathbf{V}$ (with minor by-products), as was the case without added DIBAH. In the second sample, species IV was generated in ordinary way $\left((\mathrm{SBI}) \mathrm{ZrCl}_{2} / \mathrm{Al}^{i} \mathrm{Bu}_{3} /\right.$ $\left[\mathrm{CPh}_{3}\right]\left[\mathrm{B}\left(\mathrm{C}_{6} \mathrm{~F}_{5}\right)_{4}\right] \quad(\mathrm{Zr}: \mathrm{Al}: \mathrm{B}=1: 5: 1)$, excess TIBA was removed by washing with toluene, and 1,2-dichlorobenzene was added to obtain a homogeneous solution). Then, $\mathrm{HAl}^{i} \mathrm{Bu}_{2}(\mathrm{Zr} / \mathrm{Al}=1: 3.5)$ was added. After this operation, according to the ${ }^{1} \mathrm{H}$ and ${ }^{13} \mathrm{C}$ NMR spectra, IV converted to an unidentified species different from $\mathbf{V}$, whereas traces of $\mathbf{V}$ (already present in IV before the addition of DIBAH) remained unchanged. Based on these results, we concluded that DIBAH did not participate in the transformations of interest, either alone or in combination with TIBA.

\subsection{The system (SBI) ZrMe $2 / \mathrm{Al}^{i} \mathrm{Bu}_{3} /\left[\mathrm{CPh}_{3}\right]\left[\mathrm{B}\left(\mathrm{C}_{6} F_{5}\right)_{4}\right]$}

The situation regarding the zirconocene dimethyl system ( $\mathrm{SBI}) \mathrm{ZrMe}_{2} / \mathrm{Al}^{i} \mathrm{Bu}_{3} /\left[\mathrm{CPh}_{3}\right]\left[\mathrm{B}\left(\mathrm{C}_{6} \mathrm{~F}_{5}\right)_{4}\right]$ is somewhat different. First of all, low $\mathrm{Al} / \mathrm{Zr}$ ratios could not be used here, because even at $\mathrm{Al} / \mathrm{Zr}=10$ only $50 \%$ of $\mathrm{Zr}$ were converted to (SBI) $\mathrm{ZrMeBu}{ }^{i}$. Thus, a high excess of TIBA was used for sample preparation. It was found that after stirring the mixture $(\mathrm{SBI}) \mathrm{ZrMe}_{2} \mathrm{AlBu}_{3}^{i}\left[\mathrm{CPh}_{3}\right]\left[\mathrm{B}\left(\mathrm{C}_{6} \mathrm{~F}_{5}\right)_{4}\right](\mathrm{Zr}: \mathrm{Al}: \mathrm{B}=$ $1: 40: 1)$ for $15 \mathrm{~min}$ at room temperature, ca. $70 \%$ of the zirconium complex was converted to species $\mathbf{V}$ (Scheme 4) along with minor unidentified by-products.

An experiment with $(\mathrm{SBI}) \mathrm{ZrMe}_{2} /\left[\mathrm{CPh}_{3}\right]\left[\mathrm{B}\left(\mathrm{C}_{6} \mathrm{~F}_{5}\right)_{4}\right](\mathrm{Zr}$ : $\mathrm{B}=1: 1)$ clearly indicated the formation of known [11] species $[(\mathrm{SBI}) \mathrm{ZrMe}(\mathrm{S})]\left[\mathrm{B}\left(\mathrm{C}_{6} \mathrm{~F}_{5}\right)_{4}\right]$ III (see Section 4). Addition of $\mathrm{AlBu}_{3}^{i}(\mathrm{Al}: \mathrm{Zr}=3)$ immediately converted III into species $\mathbf{V}$ as the only zirconium product.

Nevertheless, an experiment with (SBI) $\mathrm{ZrMe}_{2} \mathrm{AlBu}_{3}^{i}$ $\left[\mathrm{CPh}_{3}\right]\left[\mathrm{B}\left(\mathrm{C}_{6} \mathrm{~F}_{5}\right)_{4}\right](\mathrm{Zr}: \mathrm{Al}: \mathrm{B}=1: 5: 1)$ was undertaken and showed the formation of a red-brown oil containing a mixture of at least three zirconium species, all of which had mostly broad NMR lines. One of them is species $\mathbf{V}$, however, we failed to assign other signals due to their broad line widths and overlapping signals. The reaction mixture was unstable and converted to complexes of the type $\mathbf{V}$ (i.e. having ${ }^{1} \mathrm{H}$ peaks in the range of $\delta-1$ to -4 ) in the presence of a 2-3-fold excess of residual TIBA. After $12 \mathrm{~h}$, mainly $\mathbf{V}$ was detected in the mixture.

Cationic hydride species are capable of initiating isobutene polymerization $[22,31,32]$. When different amounts of isobutene [(a) ca. 1 equiv.; (b) ca. 40 equiv.] were added to the NMR tube containing $\mathbf{V}$ and stirred for several minutes, the ${ }^{1} \mathrm{H}$ and ${ }^{13} \mathrm{C}$ NMR spectra showed dissolved polyisobutene $\left({ }^{13} \mathrm{C}, \delta 60.0, \mathrm{CH}_{2} ; \delta 38.6, C ; \delta 31.7, \mathrm{CH}_{3}\right)$, alongside unchanged species $\mathbf{V}$.

\subsection{On the nature of the intermediates}

Thus, at given concentrations $([\mathrm{Zr}]=0.02-0.1 \mathrm{M},[\mathrm{Al}]=$ $0.5-1.6 \mathrm{M}$ ) species $\mathbf{I V}$ and $\mathbf{V}$ co-exist in solution, so that an excess of TIBA is required to convert IV into V. Once formed, IV could either transform into the active species (via replacement of the chloride ligand by isobutyl, as in the iron-based system reported by Babik and Fink [33]) with subsequent monomer insertion and chain propagation or react with TIBA to yield $\mathbf{V}$ (Scheme 5). Apparently, the latter reaction route is realized in the absence of the monomer. In practical polymerizations, the concentration of TIBA are 3-4 orders of magnitude lower than in this NMR study, so the formation of $\mathbf{V}$ should be much slower than monomer insertion and further polymerization. Besides, complex IV showed evident activity in propylene polymerization and is, therefore, the most likely precursor of the polymerizing species in the $(\mathrm{SBI}) \mathrm{ZrX}_{2} / \mathrm{AlBu}_{3}^{i} /$ $\left[\mathrm{CPh}_{3}\right]\left[\mathrm{B}\left(\mathrm{C}_{6} \mathrm{~F}_{5}\right)_{4}\right]$ catalysts.

The picture looks slightly different in the system rac- $(\mathrm{SBI}) \mathrm{ZrMe}_{2} \mathrm{AlBu}_{3}^{i}\left[\mathrm{CPh}_{3}\right]\left[\mathrm{B}\left(\mathrm{C}_{6} \mathrm{~F}_{5}\right)_{4}\right]$ in this case, the ability of cationic species $[(\mathrm{SBI}) \mathrm{ZrMe}(\mathrm{S})]\left[\mathrm{B}\left(\mathrm{C}_{6} \mathrm{~F}_{5}\right)_{4}\right]$ III itself to undergo monomer insertion and chain growth cannot be excluded [29]; otherwise, the methyl ligand in III can be likewise substituted by isobutyl to form the cationic active species presumed to be present in the $(\mathrm{SBI}) \mathrm{ZrCl}_{2} /$ $\mathrm{AlBu}_{3}^{i} /\left[\mathrm{CPh}_{3}\right]\left[\mathrm{B}\left(\mathrm{C}_{6} \mathrm{~F}_{5}\right)_{4}\right]$ system.

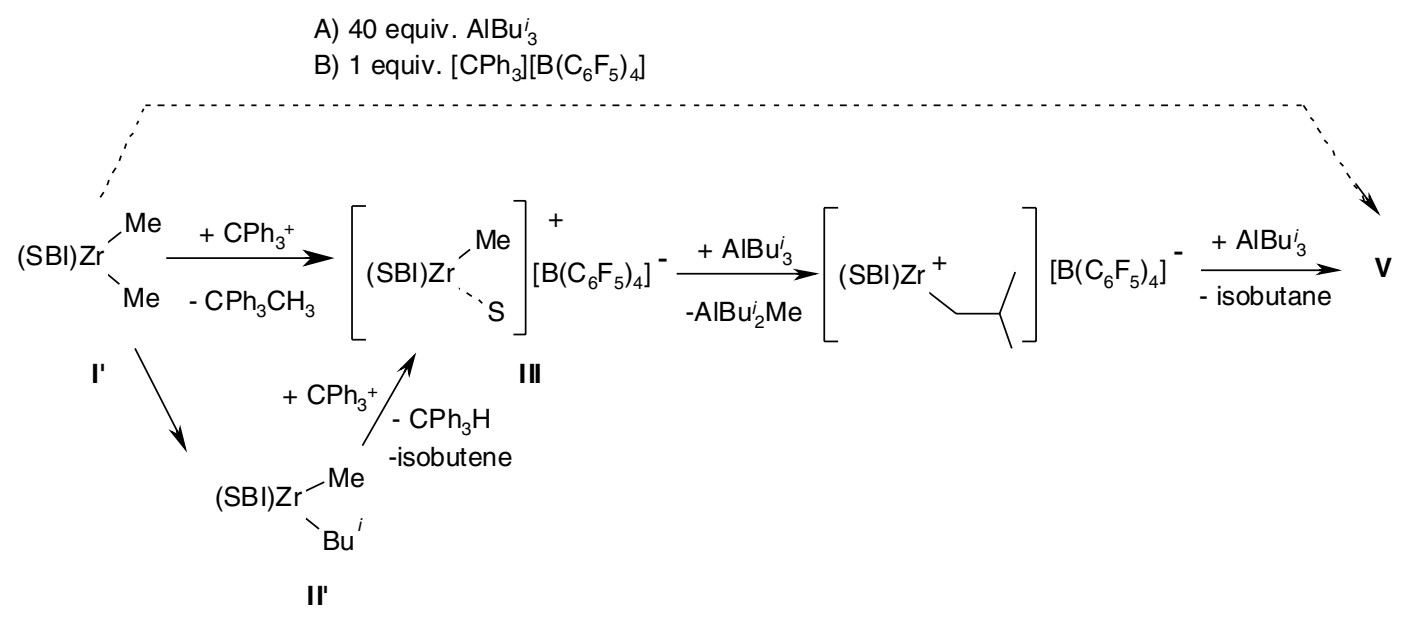

Scheme 4. Reaction routes proposed for $(\mathrm{SBI}) \mathrm{ZrMe}_{2}$. 


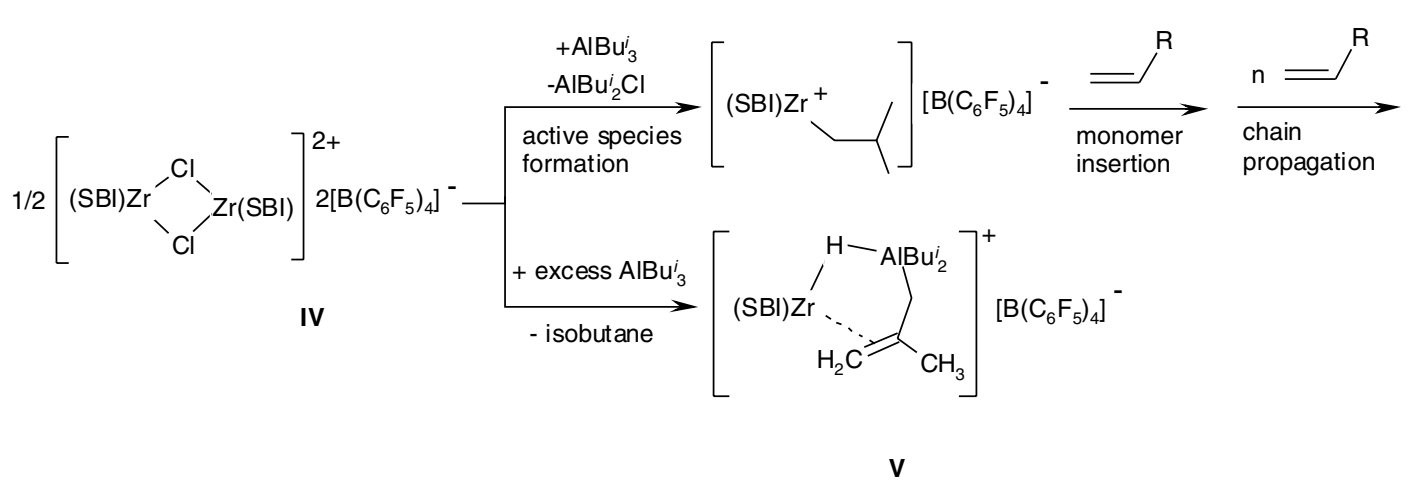

Scheme 5. Possible reactions of complex IV.

\section{Conclusions}

The cationic zirconium(IV) species formed in ternary systems $(\mathrm{SBI}) \mathrm{ZrX}_{2} / \mathrm{AlBu}_{3}^{i} /\left[\mathrm{CPh}_{3}\right]\left[\mathrm{B}\left(\mathrm{C}_{6} \mathrm{~F}_{5}\right)_{4}\right]$, where $\mathrm{X}=$ $\mathrm{Cl}, \mathrm{Me}$, were studied by multinuclear NMR spectroscopy. In the first system $(\mathrm{X}=\mathrm{Cl})$, the crystallographically characterized $\left[(\mathrm{SBI}) \mathrm{Zr}(\mu-\mathrm{Cl})_{2} \mathrm{Zr}(\mathrm{SBI})\right]\left[\mathrm{B}\left(\mathrm{C}_{6} \mathrm{~F}_{5}\right)_{4}\right]_{2}$ ion pair IV predominates at low $\mathrm{Al} / \mathrm{Zr}$ ratios $(\mathrm{Al} / \mathrm{Zr}<10)$, while at higher $\mathrm{Al} / \mathrm{Zr}$ ratios $(\geqslant 20)$ mainly $\left[(\mathrm{SBI}) \mathrm{Zr}(\mu-\mathrm{H})\left(\mu-\mathrm{C}_{4} \mathrm{H}_{7}\right)\right.$ $\left.\mathrm{Al}^{i} \mathrm{Bu}_{2}\right]\left[\mathrm{B}\left(\mathrm{C}_{6} \mathrm{~F}_{5}\right)_{4}\right](\mathbf{V})$ is formed. In the presence of excess TIBA, species IV was shown to polymerize propylene and is the most likely precursor of the active sites of propylene polymerization. Species $\mathbf{V}$ is formed in both systems at high $\mathrm{Al} / \mathrm{Zr}$ ratios in the absence of monomer and is probably the thermodynamic sink of the catalyst.

\section{Experimental}

\subsection{General}

Triisobutylaluminum (TIBA) was purchased from Tomskneftekhim as toluene solution $(\leqslant 2 \% \mathrm{Al}$ as DIBAH, total $\mathrm{Al}$ content $1.6 \mathrm{M}$, containing some dissolved isobutene and isobutane) and diluted to obtain a solution of $[\mathrm{Al}]=0.5 \mathrm{M}$ or used as received for experiments with high $\mathrm{Al} / \mathrm{Zr}$ ratios. DIBAH was a commercial reagent (Aldrich) and used as $0.84 \mathrm{M}$ solution in hexanes. Trimethylaluminum (TMA) was purchased from Aldrich. Toluene was purified by refluxing over sodium metal and distilled under dry nitrogen. 1,2-Difluorobenzene and 1,2-dichlorobenzene were dried over molecular sieves $(4 \AA)$. All operations were carried out under dry nitrogen $(99.999 \%)$ by standard Schlenk techniques. Solids and toluene were transferred and stored in a glove box. (SBI) $\mathrm{ZrCl}_{2}$ [34], (SBI) $\mathrm{ZrMe}_{2}$ [35] and $\left[\mathrm{Ph}_{3} \mathrm{C}\right]\left[\mathrm{B}\left(\mathrm{C}_{6} \mathrm{~F}_{5}\right)_{4}\right]$ [36] were synthesized following the literature methods.

${ }^{1} \mathrm{H},{ }^{13} \mathrm{C},{ }^{19} \mathrm{~F}$ NMR spectra were recorded in standard $5 \mathrm{~mm}$ NMR tubes on Bruker Avance DPX-300 or Avance DPX-250 spectrometers. Typical operating conditions for ${ }^{13} \mathrm{C}$ NMR measurements were the following: spectral width $20 \mathrm{kHz}$; spectrum accumulation frequency $0.2-0.1 \mathrm{~Hz}$; $100-10,000$ transients, $90^{\circ}$ pulse at $6.7 \mu \mathrm{s}$. Correct integral values were obtained from inverse gated spectra. ${ }^{13} \mathrm{C},{ }^{1} \mathrm{H}-$ correlations were established by using standard Bruker $\mathrm{HXCOBI}$ (for direct $\mathrm{C}-\mathrm{H}$ interactions) and COLOC (for long-range $\mathrm{C}-\mathrm{H}$ interactions) pulse programs. Operating conditions for ${ }^{1} \mathrm{H}$ NMR measurements: spectral width $5 \mathrm{kHz}$; spectrum accumulation frequency $0.2-0.5 \mathrm{~Hz}$; number of transients $32-64$, ca. $30^{\circ}$ pulse at $2 \mu$ s. Typical operating conditions for ${ }^{19} \mathrm{~F}$ NMR measurements: spectral width $30 \mathrm{kHz}$; spectrum accumulation frequency $0.1-$ $0.5 \mathrm{~Hz}$; number of transients 32-64. For calculations of ${ }^{1} \mathrm{H}$ and ${ }^{13} \mathrm{C}$ chemical shifts, the resonance of the $\mathrm{CH}_{3}$-group of toluene solvent was taken as $\delta 2.09$ and 21.40 , respectively. ${ }^{19} \mathrm{~F}$ chemical shifts were referenced externally to $\mathrm{CFCl}_{3}$. Sample temperature measurements uncertainty and temperature reproducibility were less than $\pm 1{ }^{\circ} \mathrm{C}$.

\subsection{Preparation of NMR samples}

The appropriate amounts of zirconium complex (typically, $0.02-0.15 \mathrm{mmol})$ and $\left[\mathrm{CPh}_{3}\right]\left[\mathrm{B}\left(\mathrm{C}_{6} \mathrm{~F}_{5}\right)_{3}\right]$ were placed in $5 \mathrm{~mm}$ NMR tubes in a glove box and capped with rubber septa. Further addition of $\mathrm{AlBu}_{3}^{i}$ solution $(\mathrm{Al} / \mathrm{Zr}=1$, $2,3,5,10)$ to the tube with the zirconium complex was performed outside the glove box with gas-tight microsyringes. After recording the NMR spectra of the resulting complex II, the solution was transferred into the tube with $\left[\mathrm{CPh}_{3}\right]\left[\mathrm{B}\left(\mathrm{C}_{6} \mathrm{~F}_{5}\right)_{3}\right]$ upon slight cooling. The sample was shaken for several minutes while warming to room temperature. After phase separation, the organic (upper) phase was removed and, if necessary, the blue or green-blue oily phase was washed with toluene $(1 \times 1 \mathrm{~mL}$ or $2 \times 1 \mathrm{~mL})$. After that, NMR spectra of complex IV were recorded either directly in the oily phase, or $0.1-0.2 \mathrm{~mL} 1,2$-dichlorobenzene (or 1,2-difluorobenzene) was added to the oily phase to obtain a homogeneous solution. Reactions with high excesses of TIBA ( $\mathrm{Al} / \mathrm{Zr}=20$ or 30$)$ were performed in a $10 \mathrm{~mL}$ Schlenk flask, with magnetic stirring for 15 $30 \mathrm{~min}$. After that, the organic phase was removed, and the brown oily residue containing complex $\mathbf{V}$ was washed with toluene, diluted with 1,2-dichlorobenzene and injected in an NMR tube with nitrogen atmosphere.

Propylene and isobutene were injected in the NMR tubes via gas-tight syringes. An experiment with addition of high excess of isobutene was performed as follows: a 
$50 \mathrm{~mL}$ flask with a magnetic stirrer was charged with ca. $0.05 \mathrm{mmol}$ of complex $\mathbf{V}$ in toluene/1,2-dichlorobenzene, cooled in the bottom part to freeze the solution, evacuated, filled with isobutene atmosphere and allowed to warm to room temperature at $500 \mathrm{rpm}$ stirring for $15 \mathrm{~min}$.

\subsection{NMR data for zirconium complexes}

Hereinafter, only clearly detected signals are presented. Some of the peaks in the aromatic region are overlapped with toluene and 1,2-difluorobenzene resonances.

\subsection{1. ( $\mathrm{SBI}) \mathrm{ZrCl}_{2}$}

${ }^{1} \mathrm{H}$ NMR (toluene, $\left.20^{\circ} \mathrm{C}\right): \delta 5.66(\mathrm{~d}, 2 \mathrm{H}, \mathrm{Cp}-H$, $J_{\mathrm{HH}}=3 \mathrm{~Hz}$; the second Cp doublet is masked by toluene peaks), 0.55 (s, $\left.6 \mathrm{H}, \mathrm{Si}\left(\mathrm{CH}_{3}\right)_{2}\right)$.

${ }^{13} \mathrm{C}$ NMR (toluene, $\left.50{ }^{\circ} \mathrm{C}\right): \delta 118.0(2 \mathrm{C}$, Ind), $117.5(2 \mathrm{C}$, Ind $),-1.88\left(2 \mathrm{C}, \mathrm{Si}\left(\mathrm{CH}_{3}\right)_{2}\right)$. Few signals were found due to low solubility of $(\mathrm{SBI}) \mathrm{ZrCl}_{2}$.

\subsection{2. ( $\mathrm{SBI}) \mathrm{ZrMe}_{2}$}

${ }^{1} \mathrm{H}$ NMR (toluene, $\left.20{ }^{\circ} \mathrm{C}\right): \delta 6.61(\mathrm{~d}, 2 \mathrm{H}, \mathrm{Cp}-H$, $\left.J_{\mathrm{HH}}=3 \mathrm{~Hz}\right), 5.61\left(\mathrm{~d}, 2 \mathrm{H}, \mathrm{Cp}-H, J_{\mathrm{HH}}=3 \mathrm{~Hz}\right), 0.53(\mathrm{~s}$, $\left.6 \mathrm{H}, \mathrm{Si}\left(\mathrm{CH}_{3}\right)_{2}\right),-1.10\left(\mathrm{~s}, 6 \mathrm{H}, \mathrm{Zr}\left(\mathrm{CH}_{3}\right)_{2}\right)$.

${ }^{13} \mathrm{C}$ NMR (toluene, $20{ }^{\circ} \mathrm{C}$ ): $\delta 126.0$ (2C, Ind), 125.0 (2C, Ind), 124.9 (2C, Ind), 124.5 (2C, Ind), 117.8 (2C, Ind), 111.4 (2C, Ind), 84.4 (2C, $\mathrm{Si}-\mathrm{C}(\mathrm{Cp})), 37.1\left(2 \mathrm{C}, \mathrm{Zr}\left(\mathrm{CH}_{3}\right)_{2}\right)$, $-1.9\left(2 \mathrm{C}, \mathrm{Si}\left(\mathrm{CH}_{3}\right)_{2}\right)$.

\subsubsection{Reaction of ( $\mathrm{SBI}) \mathrm{ZrCl}_{2}$ with $\mathrm{AlBu}_{3}^{i}$ :}

( $\mathrm{SBI}) \mathrm{ZrCl}\left(\mathrm{Bu}^{i}\right)$ (II)

At $\mathrm{TIBA} / \mathrm{Zr}=5,[\mathrm{Zr}]=0.02 \mathrm{M}, \sim 90 \%$ conversion of (SBI) $\mathrm{ZrCl}_{2}$ into II was observed.

${ }^{1} \mathrm{H}$ NMR (toluene, $20{ }^{\circ} \mathrm{C}$, TIBA $/ \mathrm{Zr}=5,[\mathrm{Zr}]=0.02 \mathrm{M}$ ): $\delta 5.85\left(\mathrm{~d}, 1 \mathrm{H}, \mathrm{Cp}-H, J_{\mathrm{HH}}=3 \mathrm{~Hz}\right), 5.45(\mathrm{~d}, 1 \mathrm{H}, \mathrm{Cp}-H$, $\left.J_{\mathrm{HH}}=3 \mathrm{~Hz}\right), 0.84\left(\mathrm{~s}, 3 \mathrm{H},-\mathrm{CH}_{2} \mathrm{CH}\left(\mathrm{CH}_{3}\right)_{2}\right), 0.82(\mathrm{~s}, 3 \mathrm{H}$, $\left.-\mathrm{CH}_{2} \mathrm{CH}\left(\mathrm{CH}_{3}\right)_{2}\right), 0.55 \quad\left(\mathrm{~s}, 3 \mathrm{H}, \quad \mathrm{SiCH}_{3}\right), 0.47 \quad(\mathrm{~s}, 3 \mathrm{H}$, $\left.\mathrm{SiCH}_{3}\right),-0.56^{(*)}\left(\mathrm{dd}, \quad 1 \mathrm{H}, \quad \mathrm{Zr}-\mathrm{CH} H-, \quad J_{\mathrm{HH}}=12.7 \mathrm{~Hz}\right.$, $\left.J_{\mathrm{HH}}=5.8 \mathrm{~Hz}\right),-0.93^{(*)}\left(\mathrm{dd}, 1 \mathrm{H}, \mathrm{Zr}-\mathrm{CH} H-, J_{\mathrm{HH}}=12.7 \mathrm{~Hz}\right.$, $\left.J_{\mathrm{HH}}=6.2 \mathrm{~Hz}\right) .^{(*)}-$ peak positions are concentration dependent.

${ }^{13} \mathrm{C}$ NMR (toluene, $20{ }^{\circ} \mathrm{C}, \quad \mathrm{TIBA} / \mathrm{Zr}=5, \quad[\mathrm{Zr}]=$ $0.02 \mathrm{M}): \delta 118.5$ (1C, Ind), 116.9 (1C, Ind), 114.8 (1C, Ind), 112.2 (1C, Ind), $87.6(1 \mathrm{C}, \mathrm{Si}-C(\mathrm{Cp})), 86.9$ (1C, $\mathrm{Si}-\mathrm{C}(\mathrm{Cp})), 83.0 \quad\left(1 \mathrm{C}, \mathrm{Zr}-\mathrm{CH}_{2}\right)^{(*)}, 33.2 \quad\left(1 \mathrm{C}, \mathrm{Zr}-\mathrm{CH}_{2-}\right.$ $\left.\mathrm{CH}\left(\mathrm{CH}_{3}\right)_{2}\right),-1.69\left(1 \mathrm{C}, \mathrm{Si}-\mathrm{CH}_{3}\right),-2.47\left(\mathrm{Si}-\mathrm{CH}_{3}\right) .{ }^{(*)}$ peak position is concentration dependent; at TIBA/ $\mathrm{Zr}=10,[\mathrm{Zr}]=0.065 \mathrm{M}, \mathrm{Zr}-\mathrm{CH}_{2}-$ peak was found at $88.3 \mathrm{ppm}$.

\subsubsection{Independent preparation of ( $\mathrm{SBI}) \mathrm{Zr}(\mathrm{Cl}) \mathrm{CH}_{2} \mathrm{CHMe}_{2}$ (II)}

$(\mathrm{SBI}) \mathrm{ZrCl}_{2} \quad(0.20 \mathrm{~g} \quad(0.45 \mathrm{mmol}))$ was suspended in $50 \mathrm{~mL}$ of toluene at $0{ }^{\circ} \mathrm{C}$. To the suspension $1.0 \mathrm{~mL}$ of $\mathrm{MgClCH}_{2} \mathrm{CHMe}_{2}$ was added slowly. After the reaction mixture was stirred at $0{ }^{\circ} \mathrm{C}$ for $2 \mathrm{~h}$, the temperature was raised to $10{ }^{\circ} \mathrm{C}$ and it was stirred $10 \mathrm{~h}$ with the temperature maintained at $10{ }^{\circ} \mathrm{C}$. Filtering off the solid residues and the removal of volatiles gave an orange solid, which was washed with $10 \mathrm{ml}$ of light petroleum and dried to afford the orange product $0.20 \mathrm{~g}(96 \%)$.

${ }^{1} \mathrm{H}$ NMR (toluene- $\left.d_{8}, 20{ }^{\circ} \mathrm{C}\right): \delta 7.59(\mathrm{~d}, 1 \mathrm{H}, \mathrm{Ar}-H$, $\left.J_{\mathrm{HH}}=8.8 \mathrm{~Hz}\right), 7.24(\mathrm{~m}, 2 \mathrm{H}$, Ind $-H), 7.1-6.8(\mathrm{~m}, \mathrm{Cp}-H$ and Ind- $H), 6.93\left(\mathrm{~d}, 1 \mathrm{H}, \mathrm{Cp}-H, J_{\mathrm{HH}}=3 \mathrm{~Hz}\right), 5.82(\mathrm{~d}$, $\left.1 \mathrm{H}, \mathrm{Cp}-H, J_{\mathrm{HH}}=3 \mathrm{~Hz}\right), 5.60\left(\mathrm{~d}, 1 \mathrm{H}, \mathrm{Cp}-H, J_{\mathrm{HH}}=3 \mathrm{~Hz}\right)$, $1.99\left(\mathrm{~m}, 1 \mathrm{H},-\mathrm{CH}_{2} \mathrm{CHMe}\right), 0.91\left(\mathrm{~d}, 3 \mathrm{H},-\mathrm{CH}_{2} \mathrm{CH}\left(\mathrm{CH}_{3}\right)_{2}\right.$, $\left.J_{\mathrm{HH}}=6.5 \mathrm{~Hz}\right), \quad 0.84 \quad\left(\mathrm{~d}, \quad 3 \mathrm{H}, \quad-\mathrm{CH}_{2} \mathrm{CH}\left(\mathrm{CH}_{3}\right)_{2}, \quad J_{\mathrm{HH}}=\right.$ $6.5 \mathrm{~Hz}), 0.57\left(\mathrm{~s}, 3 \mathrm{H}, \mathrm{Si}\left(\mathrm{CH}_{3}\right)_{2}\right), 0.50\left(\mathrm{~s}, 3 \mathrm{H}, \mathrm{Si}\left(\mathrm{CH}_{3}\right)_{2}\right)$, $-0.78\left(\mathrm{~m}, 1 \mathrm{H},-\mathrm{CH}_{2} \mathrm{CH}\left(\mathrm{CH}_{3}\right)_{2}\right),-0.96\left(\mathrm{~m}, 1 \mathrm{H},-\mathrm{CH}_{2} \mathrm{CH}-\right.$ $\left.\left(\mathrm{CH}_{3}\right)_{2}\right) .{ }^{13} \mathrm{C}$ NMR (toluene- $d_{8}, 20{ }^{\circ} \mathrm{C}$ ): $\delta 132.4,131.5$, (119-125 Ind-C overlapped with toluene- $\left.d_{8},\right) 118.3,116.7$, $115.3,112.0,88.0,86.9,78.0,32.1,29.1,26.4,-1.7,-2.3$.

\subsubsection{Reaction of (SBI) $\mathrm{ZrMe}_{2} /\left[\mathrm{CPh}_{3}\right]\left[B\left(\mathrm{C}_{6} F_{5}\right)_{4}\right]$ : complex III}

The starting reactants $(\mathrm{SBI}) \mathrm{ZrMe}_{2}(0.02 \mathrm{mmol})$ and $\left[\mathrm{CPh}_{3}\right]\left[\mathrm{B}\left(\mathrm{C}_{6} \mathrm{~F}_{5}\right)_{4}\right](0.02 \mathrm{mmol})$ were placed in a $5 \mathrm{~mm}$ NMR tube in a glove box and capped with septum stoppers. Then, $0.5 \mathrm{ml}$ of toluene- $d_{8}$ and $0.2 \mathrm{ml}$ of 1,2-difluorobenzene were added and the tube was shaken for several minutes. The ${ }^{1} \mathrm{H}$ spectrum recorded after 5 min indicated the initial formation of the homobinuclear $\mathrm{Zr}$ species $\left[\{(\mathrm{SBI}) \mathrm{ZrMe}\}_{2}(\mu-\mathrm{Me})\right]\left[\mathrm{B}\left(\mathrm{C}_{6} \mathrm{~F}_{5}\right)_{4}\right]$ (both diastereomers). After storing the sample for several hours at room temperature, formation of $[(\mathrm{SBI}) \mathrm{ZrMe}(\mathrm{S})]\left[\mathrm{B}\left(\mathrm{C}_{6} \mathrm{~F}_{5}\right)_{4}\right]$ (III) was revealed by ${ }^{1} \mathrm{H}$ NMR. No coordination of anion to zirconium was observed by ${ }^{19} \mathrm{~F}$ NMR.

${ }^{1} \mathrm{H}$ NMR (complex $[(\mathrm{SBI}) \mathrm{ZrMe}(\mathrm{S})]\left[\mathrm{B}\left(\mathrm{C}_{6} \mathrm{~F}_{5}\right)_{4}\right]$, toluene/ 1,2-difluorobenzene, $\left.\quad 2{ }^{\circ} \mathrm{C}\right): \quad \delta \quad 5.30 \quad(\mathrm{~d}, \quad 1 \mathrm{H}, \quad \mathrm{Cp}-H$, $\left.J_{\mathrm{HH}}=3 \mathrm{~Hz}\right), 5.04(\mathrm{~d}, 1 \mathrm{H}, \mathrm{Cp}-H), 0.60\left(\mathrm{~s}, 3 \mathrm{H}, \mathrm{Si}\left(\mathrm{CH}_{3}\right)_{2}\right)$, 0.35 (s, $\left.3 \mathrm{H}, \mathrm{Si}\left(\mathrm{CH}_{3}\right)_{2}\right),-0.67$ (s, 3H, $\left.\mathrm{Zr}-\mathrm{CH}_{3}\right) ; 1.99 \mathrm{ppm}$ (s, $3 \mathrm{H}, \mathrm{CPh}_{3} \mathrm{CH}_{3}$ ).

${ }^{13} \mathrm{C}$ NMR (complex $[(\mathrm{SBI}) \mathrm{ZrMe}(\mathrm{S})]\left[\mathrm{B}\left(\mathrm{C}_{6} \mathrm{~F}_{5}\right)_{6}\right]$, toluene/ 1,2-difluorobenzene, $\left.2{ }^{\circ} \mathrm{C}\right): \delta 58.3\left(1 \mathrm{C}, \mathrm{Zr}-\mathrm{CH}_{3}\right),-2.74$ $\left(1 \mathrm{C}, \mathrm{Si}\left(\mathrm{CH}_{3}\right)_{2}\right),-4.16\left(1 \mathrm{C}, \mathrm{Si}\left(\mathrm{CH}_{3}\right)_{2}\right) ; 52.6\left(\mathrm{Ph}_{3} \mathrm{CCH}_{3}\right)$, $30.3\left(\mathrm{Ph}_{3} \mathrm{CCH}_{3}\right)$.

${ }^{19} \mathrm{~F}$ NMR (complex $[(\mathrm{SBI}) \mathrm{ZrMe}(\mathrm{S})]\left[\mathrm{B}\left(\mathrm{C}_{6} \mathrm{~F}_{5}\right){ }_{4}\right]$, toluene/ 1,2-difluorobenzene, $\left.2{ }^{\circ} \mathrm{C}\right): \delta-132.5(2 \mathrm{~F}, o-\mathrm{F}),-162.9(\mathrm{t}$, $\left.1 \mathrm{~F}, p-\mathrm{F}, J_{\mathrm{FF}}=20.7 \mathrm{~Hz}\right),-166.9(\mathrm{t}, 2 \mathrm{~F}, m-\mathrm{F})$.

This complex displays a well-documented ion pair symmetrization $[11 \mathrm{~b}, 37,38]$ leading to coalescence of the $\mathrm{Cp}-H$ and $\mathrm{Si}(\mathrm{Me})_{2} \mathrm{NMR}$ peaks at $+20{ }^{\circ} \mathrm{C}$. The ${ }^{1} \mathrm{H}$ NMR data at $+22^{\circ} \mathrm{C}$ are presented below. The estimated apparent $\Delta G_{\mathrm{ex}}^{\neq}$ value of $14 \mathrm{kcal} \mathrm{mol}^{-1}$ (at $20^{\circ} \mathrm{C}$ ) is close to those observed for similar exchange processes [11b,37].

${ }^{1} \mathrm{H}$ NMR (complex $[(\mathrm{SBI}) \mathrm{ZrMe}(\mathrm{S})]\left[\mathrm{B}\left(\mathrm{C}_{6} \mathrm{~F}_{5}\right)_{4}\right]$, toluene/ 1,2-difluorobenzene, $\left.-22{ }^{\circ} \mathrm{C}\right): \delta 5.28(\mathrm{br}, 2 \mathrm{H}, \mathrm{Cp}-H), 0.54$ (br, $\left.6 \mathrm{H}, \mathrm{Si}\left(\mathrm{CH}_{3}\right)_{2}\right),-0.65$ (s, 3H, $\left.\mathrm{Zr}-\mathrm{CH}_{3}\right)$.

\subsection{6. $\mathrm{NMR}$ reaction of ( $\mathrm{SBI}) \mathrm{ZrCl}_{2} / \mathrm{Al}\left(\mathrm{Bu}^{i}\right)_{3} /$ \\ $\left[\mathrm{CPh}_{3}\right]\left[\mathrm{B}\left(\mathrm{C}_{6} F_{5}\right)_{4}\right]$ : complex $\mathbf{I V}$}

Complex IV was predominantly formed at $\mathrm{Al} / \mathrm{Zr}$ ratios of 5-10 after 3-15 min shaking of the NMR tube with (SBI) $\mathrm{ZrCl}_{2}+\mathrm{AlBu}_{3}^{i}+\left[\mathrm{CPh}_{3}\right]\left[\mathrm{B}\left(\mathrm{C}_{6} \mathrm{~F}_{5}\right)_{4}\right]$. IV formed a 
green or blue-green oil in the NMR tube. It is stable for days in a fridge and at least 2 days at room temperature. Surprisingly, washings with toluene did not remove all TIBA: even after $2 \times 1 \mathrm{~mL}$ washings, ca. 1.5 molecules of TIBA per one $\mathrm{Zr}$ complex were found in the reaction mixture.

${ }^{1} \mathrm{H}$ NMR (toluene/1,2-dichlorobenzene, $20{ }^{\circ} \mathrm{C}$ ): $\delta 6.42$ $\left(\mathrm{d}, \quad 2 \mathrm{H}, \quad \mathrm{Cp}-H, \quad J_{\mathrm{HH}}=3 \mathrm{~Hz}\right), \quad 5.39(\mathrm{~d}, \quad 2 \mathrm{H}, \quad \mathrm{Cp}-H$, $\left.J_{\mathrm{HH}}=3 \mathrm{~Hz}\right), 0.84\left(\mathrm{~s}, 6 \mathrm{H}, \mathrm{Si}\left(\mathrm{CH}_{3}\right)_{2}\right) ; 5.31\left(\mathrm{~s}, 1 \mathrm{H}, \mathrm{CPh}_{3} H\right)$.

${ }^{13} \mathrm{C}$ NMR (toluene/1,2-dichlorobenzene, $20{ }^{\circ} \mathrm{C}$ ): $\delta 135.0$ (2C, Ind), 127.1 (2C, Ind), 127.0 (2C, Ind), 124.0 (2C, Ind), 122.6 (2C, Ind), 121.6 (2C, Ind), 88.2 (2C, $\mathrm{Si}-C(\mathrm{Cp})),-2.9$ $\left(2 \mathrm{C}, \mathrm{Si}\left(\mathrm{CH}_{3}\right)_{2}\right) ; 57.5\left(1 \mathrm{C}, \mathrm{CPh}_{3} \mathrm{H}\right)$.

${ }^{19} \mathrm{~F}$ NMR (toluene/1,2-dichlorobenzene, $20{ }^{\circ} \mathrm{C}$ ): $\delta$ $-133.3(2 \mathrm{~F}, o-\mathrm{F}),-163.9\left(1 \mathrm{~F}, p-\mathrm{F}, J_{\mathrm{FF}} 20.7 \mathrm{~Hz}\right),-167.7$ (2F, $m-\mathrm{F})$.

Complex IV can equally be obtained by the reaction of the independently prepared $(\mathrm{SBI}) \mathrm{Zr}(\mathrm{Cl}) \mathrm{CH}_{2} \mathrm{CHMe}_{2}$ (II) with 1 equiv. of $\left[\mathrm{CPh}_{3}\right]\left[\mathrm{B}\left(\mathrm{C}_{6} \mathrm{~F}_{5}\right)_{4}\right]$.

\subsection{7. $\mathrm{NMR}$ reaction of ( $\mathrm{SBI}) \mathrm{ZrCl}_{2} / \mathrm{Al}\left(\mathrm{Bu}^{\mathrm{i}}\right)_{3} \mathrm{l}$} $\left[C P h_{3}\right]\left[B\left(C_{6} F_{5}\right)_{4}\right]$ : single crystals of complex $\left[(\mathrm{SBI}) \mathrm{Zr}(\mu-\mathrm{Cl})_{2} \mathrm{Zr}(\mathrm{SBI})\right]\left[\mathrm{B}\left(\mathrm{C}_{6} \mathrm{~F}_{5}\right)_{4}\right]_{2}(\mathrm{IV})$

Complex IV was generated at $\mathrm{Al} / \mathrm{Zr}$ ratios of $5: 1$ after 5 min shaking of the NMR tube with $(\mathrm{SBI}) \mathrm{ZrCl}_{2}+$ $\mathrm{AlBu}_{3}^{i}\left[\mathrm{CPh}_{3}\right]\left[\mathrm{B}\left(\mathrm{C}_{6} \mathrm{~F}_{5}\right)_{4}\right]$ in toluene at slight cooling (ca. $0{ }^{\circ} \mathrm{C}$ ). After separation of the organic phase, the oily phase was washed with $0.5 \mathrm{~mL}$ of toluene to remove excess TIBA, and after the addition of $0.15 \mathrm{~mL}$ of 1,2-difluorobenzene a homogeneous blue-green solution resulted. The sample was exposed to ambient temperature and room light for ca. 1 week to yield green crystals that turned red after separation and washing with 1,2-difluorobenzene. X-ray diffraction revealed the dicationic dimeric structure of $[(\mathrm{SBI}) \mathrm{Zr}(\mu-$ $\left.\mathrm{Cl})_{2} \mathrm{Zr}(\mathrm{SBI})\right]\left[\mathrm{B}\left(\mathrm{C}_{6} \mathrm{~F}_{5}\right)_{4}\right]_{2}$ with co-crystallized toluene molecules (for details see Supporting information).

\subsection{8. $\mathrm{NMR}$ reaction of (SBI) $\mathrm{ZrCl}_{2} / \mathrm{Al}(\mathrm{Me})_{3} /$}

\section{$\left[\mathrm{CPh}_{3}\right]\left[\mathrm{B}\left(\mathrm{C}_{6} \mathrm{~F}_{5}\right)_{4}\right]$ : complex $\mathbf{I V}$}

Complex I $(0.05 \mathrm{mmol})$ and $\left[\mathrm{CPh}_{3}\right]\left[\mathrm{B}\left(\mathrm{C}_{6} \mathrm{~F}_{5}\right)_{4}\right]$ $(0.05 \mathrm{mmol})$ were placed in $5 \mathrm{~mm}$ NMR tubes in a glove box and capped with septum stoppers. Then, $0.34 \mathrm{M}$ $\mathrm{AlMe}_{3}$ solution $(\mathrm{Al} / \mathrm{Zr}=7.5)$ was added to the tube with the (SBI) $\mathrm{ZrCl}_{2}$ outside the glove box with a gastight microsyringe. After recording the NMR spectra of the resulting complex (SBI)ZrClMe, the solution was transferred into the tube with $\left[\mathrm{CPh}_{3}\right]\left[\mathrm{B}\left(\mathrm{C}_{6} \mathrm{~F}_{5}\right)_{4}\right]$ upon slight cooling. The sample was shaken for several minutes while warming to room temperature. Complex IV was formed along with $\left[(\mathrm{SBI}) \mathrm{Zr}(\mu-\mathrm{Me})_{2} \mathrm{AlMe}{ }_{2}\right]\left[\mathrm{B}\left(\mathrm{C}_{6} \mathrm{~F}_{5}\right)_{4}\right]$ after $3-5 \mathrm{~min}$ shaking of the NMR tube with $\left((\mathrm{SBI}) \mathrm{ZrCl}_{2}+\mathrm{AlMe}_{3}\right)+\left[\mathrm{CPh}_{3}\right]-$ $\left[\mathrm{B}\left(\mathrm{C}_{6} \mathrm{~F}_{5}\right)_{4}\right](\mathrm{Al}: \mathrm{Zr}: \mathrm{B}=1: 7 \cdot 5: 1)$. Both cationic $\mathrm{Zr}$ complexes are stable at room temperature for at least $6 \mathrm{~h}$. After phase separation, the organic (upper) phase was removed and its NMR spectrum recorded separately. Washing the oily phase with toluene $(2 \times 0.5 \mathrm{~mL}$ washings $)$ almost completely removed $\mathrm{AlMe}_{3}$. After that, $0.1 \mathrm{~mL}$ 1,2-dichloro- benzene (1,2-difluorobenzene) was added to the oily phase to obtain a homogeneous solution.

${ }^{1} \mathrm{H}$ NMR (complex $\left[(\mathrm{SBI}) \mathrm{Zr}(\mu-\mathrm{Me})_{2} \mathrm{AlMe}_{2}\right]\left[\mathrm{B}\left(\mathrm{C}_{6} \mathrm{~F}_{5}\right)_{4}\right]$, toluene/1,2-dichlorobenzene, $\left.20{ }^{\circ} \mathrm{C}\right): \delta 6.15(\mathrm{~d}, 2 \mathrm{H}, \mathrm{Cp}-H$, $\left.J_{\mathrm{HH}}=3 \mathrm{~Hz}\right), 5.05\left(\mathrm{~d}, 2 \mathrm{H}, \mathrm{Cp}-H, J_{\mathrm{HH}}=3 \mathrm{~Hz}\right), 0.70(\mathrm{~s}$, $\left.6 \mathrm{H}, \mathrm{Si}\left(\mathrm{CH}_{3}\right)_{2}\right),-0.74\left(\mathrm{~s}, 6 \mathrm{H}, \mathrm{Al}-\mathrm{CH}_{3}\right),-1.35(\mathrm{~s}, 6 \mathrm{H}, \mathrm{Al}-$ $\mathrm{CH}_{3}-\mathrm{Zr}$ ); 2.00 (s, $3 \mathrm{H}, \mathrm{CPh}_{3} \mathrm{CH}_{3}$ ).

${ }^{13} \mathrm{C}$ NMR (complex $\left[(\mathrm{SBI}) \mathrm{Zr}(\mu-\mathrm{Me})_{2} \mathrm{AlMe}_{2}\right]\left[\mathrm{B}\left(\mathrm{C}_{6} \mathrm{~F}_{5}\right)_{4}\right]$, toluene/1,2-dichlorobenzene, $20^{\circ} \mathrm{C}$ ): $\delta 124.7$ (2C, Ind), 119.0 (2C, Ind), 116.1 (2C, Ind), 85.4 (2C, $\mathrm{Si}-C(\mathrm{Cp})$ ), $34.4\left(2 \mathrm{C}, \mathrm{Al}-\mathrm{CH}_{3}-\mathrm{Zr}\right),-3.0\left(2 \mathrm{C}, \mathrm{Si}\left(\mathrm{CH}_{3}\right)_{2}\right) ;-7.3 \mathrm{ppm}$ $\left(2 \mathrm{C}, \Delta v_{1 / 2}=8 \mathrm{~Hz}, \mathrm{Al}-\mathrm{CH}_{3}\right)$.

${ }^{1} \mathrm{H}$ NMR (complex IV, toluene/1,2-dichlorobenzene, $\left.20^{\circ} \mathrm{C}\right): \delta 6.30\left(\mathrm{~d}, 2 \mathrm{H}, \mathrm{Cp}-H, J_{\mathrm{HH}}=3 \mathrm{~Hz}\right), 5.29(\mathrm{~d}, 2 \mathrm{H}$, $\left.\mathrm{Cp}-\mathrm{H}, J_{\mathrm{HH}}=3 \mathrm{~Hz}\right), 0.76\left(\mathrm{~s}, 6 \mathrm{H}, \mathrm{Si}\left(\mathrm{CH}_{3}\right)_{2}\right) ; 2.00(\mathrm{~s}, 3 \mathrm{H}$, $\mathrm{CPh}_{3} \mathrm{CH}_{3}$ ).

${ }^{13} \mathrm{C}$ NMR (complex IV, toluene/1,2-dichlorobenzene, $\left.20^{\circ} \mathrm{C}\right): \delta 124.0$ (2C, Ind), 122.5 (2C, Ind), 121.5 (2C, Ind), $88.1(2 \mathrm{C}, \mathrm{Si}-\mathrm{C}(\mathrm{Cp})),-3.1\left(2 \mathrm{C}, \mathrm{Si}\left(\mathrm{CH}_{3}\right)_{2}\right)$.

\subsubsection{Independent preparation of $\mathbf{I V}$ from $\mathbf{I I I}$}

A solution of III and $\mathrm{Ph}_{3} \mathrm{CMe}(0.02 \mathrm{mmol})$ in toluene/ 1,2-difluorobenzene was generated in an NMR tube as described above, and $\mathrm{Me}_{3} \mathrm{SiCl}(0.022 \mathrm{mmol})$ was added with a gas-tight microsyringe. The tube was shaken, and ${ }^{1} \mathrm{H}$ NMR spectrum recorded after $10 \mathrm{~min}$ indicated the quantitative formation of IV.

${ }^{1} \mathrm{H}$ NMR (complex IV, toluene/1,2-difluorobenzene, $\left.20^{\circ} \mathrm{C}\right): \delta 6.31\left(\mathrm{~d}, 2 \mathrm{H}, \mathrm{Cp}-H, J_{\mathrm{HH}}=3 \mathrm{~Hz}\right), 5.29(\mathrm{~d}, 2 \mathrm{H}$, $\left.\mathrm{Cp}-H, J_{\mathrm{HH}}=3 \mathrm{~Hz}\right), 0.91\left(\mathrm{~s}, 6 \mathrm{H}, \mathrm{Si}\left(\mathrm{CH}_{3}\right)_{2}\right) ; 2.01(\mathrm{~s}, 3 \mathrm{H}$, $\left.\mathrm{CPh}_{3} \mathrm{CH}_{3}\right), 0.23\left(\mathrm{Me}_{3} \mathrm{SiCl}\right), 0.00\left(\mathrm{SiMe}_{4}\right)$.

${ }^{13} \mathrm{C}$ NMR (complex IV, toluene/1,2-difluorobenzene, $\left.20^{\circ} \mathrm{C}\right): \delta 91.7(2 \mathrm{C}, \mathrm{Si}-\mathrm{C}(\mathrm{Cp})),-2.8\left(2 \mathrm{C}, \mathrm{Si}\left(\mathrm{CH}_{3}\right)_{2}\right)$.

\subsubsection{0. $\mathrm{NMR}$ reaction of (SBI) $\mathrm{ZrCl}_{2} / \mathrm{AlBu}_{3}^{i} /\left[\mathrm{CPh}_{3}\right]-$ [B $\left.\left(C_{6} F_{5}\right)_{4}\right]$ : complex $\boldsymbol{V}$}

Complex $\mathbf{V}$ was the dominant product formed at $\mathrm{Al} / \mathrm{Zr}$ ratios of 20-30 after $10-30 \mathrm{~min}$ magnetic stirring as described above. It is stable for at least $1 \mathrm{~d}$ at room temperature. Along with $\mathbf{V}$, residual IV was detected in the reaction mixture (ca. $20 \%$ of $\mathbf{I V}$ at $\mathrm{Al} / \mathrm{Zr}=30$ ).

${ }^{1} \mathrm{H}$ NMR (toluene/1,2-dichlorobenzene, $20{ }^{\circ} \mathrm{C}$ ): $\delta 6.26$ $\left(\mathrm{d}, \quad 1 \mathrm{H}, \quad \mathrm{Cp}-H, \quad J_{\mathrm{HH}}=3 \mathrm{~Hz}\right), \quad 5.66 \quad(\mathrm{~d}, \quad 1 \mathrm{H}, \quad \mathrm{Cp}-H$, $\left.J_{\mathrm{HH}}=3 \mathrm{~Hz}\right), 5.34\left(\mathrm{~d}, 1 \mathrm{H}, \mathrm{Cp}-H, J_{\mathrm{HH}}=3 \mathrm{~Hz}\right), 5.28(\mathrm{~d}$, $1 \mathrm{H}, \mathrm{Cp}-H, J_{\mathrm{HH}}=3 \mathrm{~Hz}$ ), $3.03\left(\mathrm{~s}, 1 \mathrm{H}, \mathrm{Zr}-\mathrm{CH} H-^{*}\right), 2.51$ (s, $\left.1 \mathrm{H}, \mathrm{Al}-\mathrm{CH} H^{-*}\right), 0.22\left(\mathrm{~s}, 1 \mathrm{H}, \mathrm{Al}-\mathrm{CH} \mathrm{H}^{-}{ }^{*}\right), 0.75(\mathrm{~s}, 3 \mathrm{H}, \mathrm{Si}-$ $\left.\mathrm{CH}_{3}\right), 0.68$ (s, 3H, Si-CH$),-1.73$ (s, $\left.1 \mathrm{H}, \mathrm{Zr}-\mathrm{CHH}^{-}{ }^{*}\right)$, -3.35 (s, $1 \mathrm{H}, \mathrm{Zr}-\mathrm{H}-\mathrm{Al})$.

${ }^{13} \mathrm{C}$ NMR (toluene/1,2-dichlorobenzene, $20{ }^{\circ} \mathrm{C}$ ): $\delta 166.6$ (1C, $-\mathrm{CH}_{2} \mathrm{CMeCH}_{2}-$ ), 121.9 (1C, Ind), 119.3 (1C, Ind), 113.0 (1C, Ind), 111.0 (1C, Ind), 108.7 (1C, Ind), 108.4 (1C, Ind), $93.0(1 \mathrm{C}, \mathrm{Si}-\mathrm{C}(\mathrm{Cp})), 86.9\left(1 \mathrm{C}, \mathrm{Zr}-\mathrm{CH}_{2^{-}}\right), 82.7$ $(1 \mathrm{C}, \mathrm{Si}-C(\mathrm{Cp})), 53.8\left(1 \mathrm{C},-\mathrm{CH}_{2}-\mathrm{Al}\right),-1.99\left(1 \mathrm{C}, \mathrm{Si}-\mathrm{CH}_{3}\right)$, $-3.82\left(1 \mathrm{C}, \mathrm{Si}-\mathrm{CH}_{3}\right)$.

${ }^{19} \mathrm{~F}$ NMR (toluene/1,2-dichlorobenzene, $20{ }^{\circ} \mathrm{C}$ ): $\delta$ $-133.0 \quad(2 \mathrm{~F}, o-\mathrm{F}), \quad-163.7 \quad\left(1 \mathrm{~F}, \quad p-\mathrm{F}, \quad J_{\mathrm{FF}}=20.7 \mathrm{~Hz}\right)$, $-167.5(2 \mathrm{~F}, m-\mathrm{F})$. 
${ }^{*}$ The geminal ${ }^{2} J_{\mathrm{HH}}$ coupling constants within the $\mathrm{Zr}$ $\mathrm{CH} H$ - and $\mathrm{Al}-\mathrm{CH} H$ - fragments are very small, so that no correlations are observed in H,H-COSY spectra. However, all necessary cross peaks are present in $\mathrm{C}, \mathrm{H}$-heteronuclear correlation spectra (see Supporting information).

\subsubsection{NMR reaction of ( $\mathrm{SBI}) \mathrm{ZrMe} / \mathrm{Al}\left(\mathrm{Bu}^{i}\right)_{3} /$ $\left[C P h_{3}\right]\left[B\left(C_{6} F_{5}\right)_{4}\right]$ : complex $\boldsymbol{V}$}

Complex $\mathbf{V}$ was the major product formed at $\mathrm{Al} / \mathrm{Zr}$ ratio 40 after 15 min magnetic stirring as described above. Along with complex $\mathbf{V}$ (ca. $70 \%$ of zirconium), two unidentified $\mathrm{Zr}$ species were detected in the reaction mixture $\left(20 \%\right.$ of a $C_{2^{-}}$ symmetric complex and $10 \%$ of a $C_{1}$-symmetric one). NMR data of thus obtained complex $\mathbf{V}$ were identical to those of complex $\mathbf{V}$ formed in $(\mathrm{SBI}) \mathrm{ZrCl}_{2} / \mathrm{AlBu}_{3}^{i} /\left[\mathrm{CPh}_{3}\right]$ $\left[\mathrm{B}\left(\mathrm{C}_{6} \mathrm{~F}_{5}\right)_{4}\right]$ system.

\subsection{Crystal structure analysis of $[(S B I) \operatorname{Zr}(\mu-$ $\left.\mathrm{Cl})_{2} \mathrm{Zr}(\mathrm{SBI})\right]\left[\mathrm{B}\left(\mathrm{C}_{6} F_{5}\right)_{4}\right]_{2}(\mathrm{IV})$}

A crystal was mounted on a glass fibre coated in nujol and fixed in a cold nitrogen stream on an Enraf-Nonius CAD4 diffractometer using Mo-K $\alpha$ radiation $(\lambda=$ $0.71073 \AA$ ). Data were collected at 153(2) K and processed with the HELENA program [39] and no absorption corrections were applied. The structure was determined by direct methods in SHELXs-97 [40]. Refinement was by full-matrix least-squares methods in sHELXs-97 [40]. Non-hydrogen atoms were refined anisotropically; hydrogen atoms were included in idealised positions and their isotropic thermal parameters were set to ride on the $U_{\text {eq }}$ values of the parent carbon atom. Scattering factors for neutral atoms were taken from [41].

Crystal data for IV: $\mathrm{C}_{51} \mathrm{H}_{26} \mathrm{BClF}_{20} \mathrm{SiZr}$, fw 1184.29; crystal size $0.3 \times 0.3 \times 0.3 \mathrm{~mm}$; monoclinic, space group $C 2 / c$ (No.15); $a=24.021(7) \AA, b=15.486(2) \AA, c=24.816(7) \AA$; $\beta=90.97(1)^{\circ} ; V=9230(4) \AA^{3} ; Z=4 ; D_{\text {calc }}=1.704 \mathrm{~g} / \mathrm{cm}^{3}$; $\mu=0.442 \mathrm{~mm}^{-1} ; \quad F(000)=4704 ;-29 \leqslant h \leqslant 29 ; 0 \leqslant k \leqslant$ $19 ; 0 \leqslant l \leqslant 30 ; 9275$ reflections collected, of which 9052 were independent $\left(R_{\mathrm{int}}=0.0889\right)$ and 3580 with $I>2 \sigma(I)$ were observed. Final $R_{1}[I>2 \sigma(I)]=0.1107, w R_{2}$ (all data) $=$ $0.3852, \quad w=1 /\left[\sigma^{2}\left(F_{\mathrm{o}}^{2}\right)+(a \cdot P)^{2}+(b \cdot P), \quad P=[\max -\right.$ $\left.\left(F_{\mathrm{o}}^{2}, 0\right)+2 F_{\mathrm{c}}^{2}\right] / 3$. The co-crystallized toluene molecule was found to be severely disordered around the sixfold axes of the benzene ring such that the methyl group was not detectable. It was treated in the refinement as a benzene molecule. The benzene ring was fitted with a rigid group constraint (regular hexagon $\mathrm{d}_{\mathrm{CC}}=1.39 \AA$ ). The temperature factors of the $6 \mathrm{C}$ atoms were refined isotropically as a free variable. All $\mathrm{H}$ atoms are calculated. The coordinates, s.o.f. and $U=0.05$ are fixed. The $\mathrm{H}$ atoms of the disordered cocrystallized toluene molecule were omitted.

\section{Acknowledgements}

This work was supported by the European Commission, INTAS grant 00-841, and the Royal Society, grant 2004/
R1-FSU. The authors are grateful to Prof. Dr. H. H. Brintzinger and Dr. S. J. Lancaster for fruitful discussions.

\section{Appendix A. Supplementary data}

CCDC 612556 contain the supplementary crystallographic data for $\mathbf{1 V}$. These data can be obtained free of charge via http://www.ccdc.cam.ac.uk/conts/retrieving. $\mathrm{html}$, or from the Cambridge Crystallographic Data Centre, 12 Union Road, Cambridge CB2 1EZ, UK; fax: (+44) 1223-336-033; or e-mail: deposit@ccdc.cam.ac.uk. Supplementary data associated with this article can be found, in the online version, at doi:10.1016/j.jorganchem. 2006.10.037.

\section{References}

[1] W.-M. Tsai, J.C.W. Chien, Polym. Mater. Sci. Eng. 67 (1992) 33.

[2] W.-M. Tsai, J.C.W. Chien, J. Polym. Sci. Part A: Polym. Chem. 32 (1994) 149.

[3] J.C.W. Chien, W. Song, M.D. Rausch, J. Polym. Sci. Part A: Polym. Chem. 32 (1994) 2387

[4] N. Naga, K. Mizunuma, Macromol. Rapid Commun. 18 (1997) 581.

[5] Z.Q. Fan, Y.H. Zhang, Q. Wang, L.X. Feng, Chin. Chem. Lett. 9 (1998) 83.

[6] A. Yano, S. Sone, S. Yamada, S. Hasegawa, A. Akimoto, Macromol. Chem. Phys. 200 (1999) 917.

[7] A. Yano, S. Hasegawa, S. Yamada, A. Akimoto, J. Mol. Catal. A: Chem. 148 (1999) 77.

[8] C. Götz, G. Luft, A. Rau, S. Schmitz, Chem. Eng. Technol. 12 (1998) 954.

[9] A.N. Panin, Z.M. Dzhabieva, P.N. Nedorezova, V.I. Tsvetkova, S.L. Saratovskikh, O.N. Babkina, N.M. Bravaya, J. Polym. Sci. Part A: Polym. Chem. 39 (2001) 1915.

[10] S.J. Lancaster, D.A. Walker, M. Thornton-Pett, M. Bochmann, Chem. Commun. (1999) 1533.

[11] (a) J. Zhou, S.J. Lancaster, D.A. Walker, S. Beck, M. ThorntonPett, M. Bochmann, J. Am. Chem. Soc. 123 (2001) 223; (b) S. Beck, S. Lieber, F. Schaper, A. Geyer, H.-H. Brintzinger, J. Am. Chem. Soc. 123 (2001) 1483.

[12] F. Song, M.D. Hannant, R.D. Cannon, M. Bochmann, Macromol. Symp. 213 (2004) 173.

[13] F. Song, R.D. Cannon, S.J. Lancaster, M. Bochmann, J. Mol. Catal. 218 (2004) 21.

[14] R.F. Jordan, Adv. Organomet. Chem. 32 (1991) 325.

[15] H.-H. Brintzinger, D. Fischer, R. Mulhaupt, B. Rieger, R.M. Waymouth, Angew. Chem., Int. Ed. Engl. 34 (1995) 1143

[16] M. Bochmann, J. Chem. Soc., Dalton Trans. (1996) 255.

[17] M. Bochmann, J. Organomet. Chem. 2004 (689) 3982.

[18] F. Song, R.D. Cannon, M. Bochmann, J. Am. Chem. Soc. 125 (2003) 7641.

[19] (a) C. Elschenbroich, A. Salzer, Organometallics - A Concise Introduction, $\mathrm{VCH}$, Weinheim, 1989, pp. 76;

(b) G. Bruno, J. Org. Chem. 30 (1965) 623.

[20] C. Götz, A. Rau, G. Luft, J. Mol. Catal. A: Chem. 184 (2002) 95.

[21] F. Song, R.D. Cannon, M. Bochmann, Chem. Commun. (2004) 542.

[22] A.G. Carr, D.M. Dawson, M. Thornton-Pett, M. Bochmann, Organometallics 16 (1999) 2933.

[23] S. Lieber, M.-H. Prosenc, H.-H. Brintzinger, Organometallics 19 (2000) 377.

[24] R. Gómez, L.H. Green, J.L. Haggit, J. Chem. Soc., Dalton Trans. (1996) 939.

[25] F. Wu, A.K. Dash, R.F. Jordan, J. Am. Chem. Soc. 126 (2004) 15360 . 
[26] M. Bochmann, S.J. Lancaster, Angew. Chem., Int. Ed. Engl. 33 (1994) 1634, and references therein.

[27] S. Beck, H.-H. Brintzinger, Inorg. Chim. Acta 270 (1998) 376.

[28] D.E. Babushkin, N.V. Semikolenova, V.A. Zakharov, E.P. Talsi, Macromol. Chem. Phys. 201 (2000) 558.

[29] K.P. Bryliakov, N.V. Semikolenova, D.V. Yudaev, V.A. Zakharov, H.-H. Brintzinger, M. Ystenes, E. Rytter, E.P. Talsi, J. Organomet. Chem. 683 (2003) 92.

[30] C.K. Johnson, M.N. Burnett, ORTEP-III (Version 1.0.2), Report ORNL-6895, Oak Ridge National Laboratory, Oak Ridge, TN, USA, 1996;

Louis J. Farrugia, Windows Version, University of Glasgow, Glasgow, Scotland, UK, 1999.

[31] B. Hessen, H.v.d. Heijden, J. Organomet. Chem. 534 (1997) 237.

[32] S. Garratt, A.G. Carr, G. Langstein, M. Bochmann, Macromolecules $36(2003) 4276$
[33] S.T. Babik, G. Fink, J. Mol. Catal. A: Chem. 188 (2002) 245.

[34] W. Spaleck, F. Küber, A. Winter, Organometallics 16 (1994) 954.

[35] M. Bochmann, S.J. Lancaster, M.B. Hursthouse, K.M.A. Malik, Organometallics 13 (1994) 2235.

[36] M. Bochmann, S.J. Lancaster, J. Organomet. Chem. 434 (1992) C1.

[37] C.L. Beswick, T.J. Marks, J. Am. Chem. Soc. 122 (2000) 10358.

[38] F. Song, S.J. Lancaster, R.D. Cannon, M. Schormann, S.M. Humphrey, C. Zuccaccia, A. Macchioni, M. Bochmann, Organometallics 24 (2005) 1315.

[39] A.L. Spek, HELENA, Utrecht University, Utrecht, The Netherlands, 1997.

[40] G.M. Sheldrick, SHELXS-97, sHELXL-97, Programs for the Solution and Refinement of Crystal Structures, Universität Göttingen, Germany, 1997.

[41] A.J.C. Wilson (Ed.), International Tables for Crystallography, vol. C, Kluwer Academic Publishers, Dordrecht, 1992, Tables 6.1.1.4 (pp. 500-502), 4.2.6.8 (pp. 219-222) and 4.2.4.2 (pp. 193-199). 